\title{
Nutritional Regulation of Human Brown Adipose Tissue
}

\author{
Karla J. Suchacki * (D) and Roland H. Stimson (D) \\ University/BHF Centre for Cardiovascular Science, The Queen's Medical Research Institute, University of \\ Edinburgh, 47 Little France Crescent, Edinburgh EH16 4TJ, UK; roland.stimson@ed.ac.uk \\ * Correspondence: karla.suchacki@ed.ac.uk
}

check for

updates

Citation: Suchacki, K.J.; Stimson, R.H. Nutritional Regulation of Human Brown Adipose Tissue. Nutrients 2021, 13, 1748.

https://doi.org/10.3390/nu13061748

Academic Editor: Ahmad Al-Mrabeh

Received: 14 March 2021

Accepted: 13 May 2021

Published: 21 May 2021

Publisher's Note: MDPI stays neutral with regard to jurisdictional claims in published maps and institutional affiliations.

Copyright: (C) 2021 by the authors. Licensee MDPI, Basel, Switzerland. This article is an open access article distributed under the terms and conditions of the Creative Commons Attribution (CC BY) license (https:/ / creativecommons.org/licenses/by/ $4.0 /)$.

Abstract: The recent identification of brown adipose tissue in adult humans offers a new strategy to increase energy expenditure to treat obesity and associated metabolic disease. While white adipose tissue (WAT) is primarily for energy storage, brown adipose tissue (BAT) is a thermogenic organ that increases energy expenditure to generate heat. BAT is activated upon cold exposure and improves insulin sensitivity and lipid clearance, highlighting its beneficial role in metabolic health in humans. This review provides an overview of BAT physiology in conditions of overnutrition (obesity and associated metabolic disease), undernutrition and in conditions of altered fat distribution such as lipodystrophy. We review the impact of exercise, dietary macronutrients and bioactive compounds on BAT activity. Finally, we discuss the therapeutic potential of dietary manipulations or supplementation to increase energy expenditure and BAT thermogenesis. We conclude that chronic nutritional interventions may represent a useful nonpharmacological means to enhance BAT mass and activity to aid weight loss and/or improve metabolic health.

Keywords: brown adipose tissue; obesity; type 2 diabetes; dietary (calorie) restriction; nutrition; energy expenditure

\section{Introduction}

Obesity and its associated comorbidities such as type 2 diabetes (T2DM), dyslipidemia and hypertension have a substantial adverse impact on health outcomes. In the UK, obesity alone accounts for $>30,000$ deaths per year and decreases life expectancy by nine years $[1,2]$. Obesity occurs when energy intake chronically exceeds energy expenditure (EE), resulting in the accumulation of excessive white adipose tissue (WAT). Despite numerous public health initiatives, rates of obesity continue to rise and currently one quarter of the adult UK population are obese and approximately two-thirds are classed as at least overweight [1]. Current anti-obesity medications act through reducing energy intake, either by inhibiting appetite or dietary fat absorption, but only two agents are licensed in the UK (orlistat and naltrexone/bupropion) and novel approaches are urgently required [3]. However, the recent discovery of brown adipose tissue (BAT) in adult humans [4-6] offers an exciting new strategy to treat obesity and associated metabolic disease by increasing EE (Figure 1). BAT is a thermogenic and highly plastic tissue and understanding the factors that control expansion of BAT mass and activation are key to determining the therapeutic potential of BAT. In this review we will focus on the nutritional regulation and dysregulation of BAT activity in health and in metabolic disease in humans. 


\begin{tabular}{|l|c|c|c|c|}
\hline & UCP1 Expression & Mitochondrial Density & Lipid droplet & Primary Functions \\
\hline White & - & Low & Uni-locular & $\begin{array}{c}\text { Energy storage } \\
\text { Endocrine }\end{array}$ \\
\hline Beige & + & Medium & Multi-locular & $\begin{array}{c}\text { Thermogenesis } \\
\text { Endocrine }\end{array}$ \\
\hline Brown & + & High & Multi-locular & $\begin{array}{c}\text { Thermogenesis } \\
\text { Endocrine }\end{array}$ \\
\hline
\end{tabular}

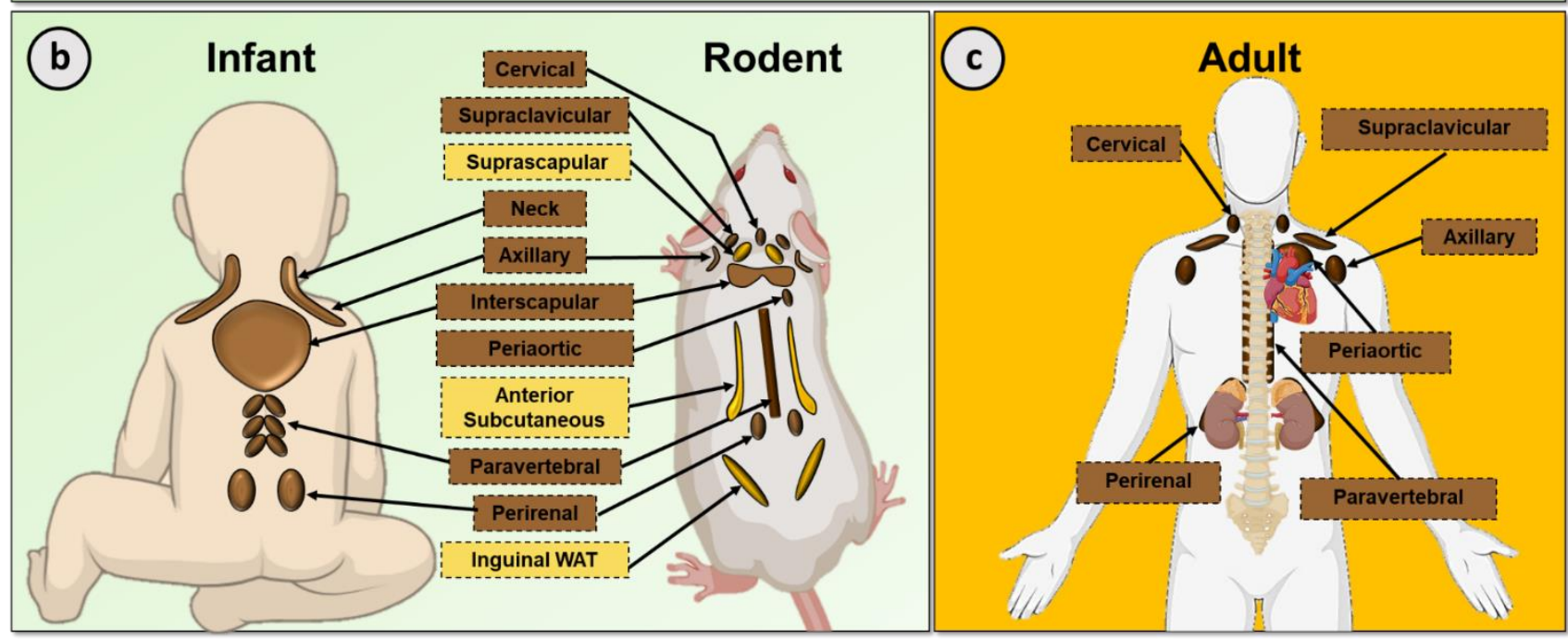

Figure 1. Adipose tissue function and location. (a) Brown adipocytes contain many UCP1 positive mitochondria, numerous small lipid droplets and are involved in thermogenesis. In contrast, white adipocytes contain few mitochondria that do not express UCP1 and a single, large lipid droplet for triglyceride storage. Beige adipocytes have an intermediate phenotype between classic brown and white adipocytes. (b) BAT is primarily located in the interscapular, neck, axillary and perirenal regions (brown boxes) in the human infant, with smaller depots behind the sternum and along the spine (human newborn) [7-9]. The size and composition of rodent BAT differs with age, sex and strain with the largest depot in the interscapular region (classical BAT) and smaller depots in the cervical, supraclavicular and peri-aortic regions. Inducible thermogenic beige adipocytes can form in specific WAT depots such as the suprascapular, anterior subcutaneous and inguinal regions (yellow boxes) [10,11]. (c) Adult human BAT is mainly located in the cervical, axillary and supraclavicular regions, with smaller depots observed in the periaortic, perirenal and paravertebral regions. Uncoupling protein 1 (UCP1), brown adipose tissue (BAT), white adipose tissue (WAT).

\section{White and Brown Adipose Tissue}

Adipose tissue exists in distinct subtypes typically classified as WAT or BAT (Figure 1). WAT is the primary organ in the body responsible for energy storage but WAT is also an important endocrine organ which regulates biological processes such as metabolic homeostasis and immunity [12]. White adipocytes contain a single large lipid droplet and few mitochondria. In contrast, BAT is a specialized thermogenic organ that increases EE to generate heat, maintaining body temperature in a cold environment [13]. In line with their thermogenic role, brown adipocytes contain substantially greater numbers of mitochondria and numerous small lipid droplets. Cold exposure stimulates BAT thermogenesis through the sympathetic nervous system via $\beta$-adrenergic receptors (classically $\beta 3$-AR but also $\beta 1-$ and $\beta 2-A R$ ) [14-16]. This subsequent signaling cascade leads to activation of the unique thermogenic protein uncoupling protein 1 (UCP1) which is situated in the inner mitochondrial membrane. UCP1 uncouples mitochondrial respiration from adenosine 
triphosphate (ATP) production, allowing the mitochondrial membrane potential to be transduced to heat. BAT thermogenesis requires a high metabolic demand, as such BAT utilizes a number of metabolic substrates including intracellular triglycerides, circulating free fatty acids (FFA) and glucose [17].

In addition to white and brown adipocytes, thermogenic 'beige' adipocytes can form under suitable stimulation such as cold exposure, for example in suprascapular, anterior subcutaneous and inguinal WAT depots in rodents in a process termed 'browning' (Figure 1b) [18]. These inducible beige adipocytes share similarities with 'classical' brown adipocytes such as containing multiple lipid droplets. Importantly, beige adipocytes also demonstrate increased glucose and FFA uptake in response to cold and contain UCP1 positive mitochondria, albeit to a lesser extent than brown adipocytes [19].

In rodents, BAT is primarily located in the interscapular region (Figure $1 \mathrm{~b}$ ) and has a critical role in nutritional homeostasis $[20,21]$. BAT is an essential organ to maintain body temperature in rodents due to their inability to defend body temperature, in part due to their greater body surface-to-weight ratio than larger mammals such as humans [22]. In addition, the important role of BAT in energy balance in rodents was identified $>40$ years ago $[23,24]$. Subsequent studies reported dysregulated BAT function in other models of obesity [25], while genetic disruption of UCP1 induced obesity in mice at thermoneutrality [20] as did ablation of BAT [21]. These studies, amongst others, underscore the importance of BAT in the maintenance of energy balance and metabolic health.

Interscapular BAT is also present in human infants (Figure 1b) which regresses soon after birth $[10,26]$. BAT depots are localized in the supraclavicular, axillary and peri-adrenal regions in the infant and smaller depots of BAT have also been recorded behind the sternum and along the spine in human newborns $[7,8,10]$. Until two decades ago, BAT was not thought to be present in adult humans; however, the development of positron emission tomography/computed tomography (PET/CT) using the metabolic tracer ${ }^{18} \mathrm{~F}$ fluorodeoxyglucose $\left({ }^{18} \mathrm{~F}-\mathrm{FDG}\right)$ to diagnose malignancies led to the incidental identification of BAT in a proportion of patients $[27,28]$. Human BAT is located primarily in the cervical, supraclavicular, paravertebral, periaortic and perirenal depots (Figure 1c) [29,30]. Morphologically, adult human BAT is a heterogeneous blend of multilocular and unilocular adipocytes [31]. Functionally, human BAT is also activated by cold exposure [4-6,32] and increases EE, insulin sensitivity and lipid clearance, highlighting the positive role of BAT in metabolic health [33-35]. Whilst the regulation of human BAT demonstrates certain similarities to rodents, for example both are activated by cold exposure [32] and are under sympathetic control [4], there are also species-specific differences [36], emphasizing the need to study BAT in humans to fully understand the mechanisms regulating this tissue. At present, the mechanisms controlling human BAT expansion and activation are not fully understood. One of the reasons behind our limited understanding of human BAT is the difficulty measuring in vivo activity. The majority of studies have used ${ }^{18} \mathrm{~F}$-FDG PET/CT to measure BAT activity, either by analysis of retrospective clinical imaging datasets or in dedicated cooling studies $[4,37,38]$. Dedicated cooling studies use a variety of methods to activate BAT, such as air (cold room)- or water-cooling protocols (water-perfused suit/blanket). Retrospective studies have a caveat, in that scans are performed at room temperature, when BAT is not as active although it still demonstrates greater glucose and FFA uptake than WAT [39,40]. In addition, the use of other novel PET tracers such as ${ }^{18} \mathrm{~F}$-fluoro-6-thia-heptadecanoic acid $\left({ }^{18} \mathrm{~F}-\mathrm{FTHA}\right)$ and ${ }^{11} \mathrm{C}$-acetate have demonstrated important biological insights such as FFA uptake and oxidative metabolism [35]. Due to certain limitations with PET/CT, alternative modalities have been sought to assess BAT morphometry and function, in part to reduce radiation exposure. To date, ${ }^{18} \mathrm{~F}-\mathrm{FDG}$ PET magnetic resonance imaging (MRI) [41], MRI [42], MR spectroscopy [43], infrared thermography [44], multispectral optoacoustic tomography [45] and microdialysis [39] have been developed as alternative/complementary techniques, some of which have provided additional insights into BAT physiology. 


\section{Dysregulation of BAT by Altered Nutritional Status}

\subsection{Overnutrition, Obesity and T2DM}

The uptake of ${ }^{18}$ F-FDG into BAT is substantially reduced with aging, obesity and T2DM $[5,32,46,47]$. Uptake of ${ }^{18}$ F-FTHA is reduced in obese subjects at both room temperature and during acute cold exposure (achieved using blankets perfused with water cooled to $\sim 10{ }^{\circ} \mathrm{C}$ for $2 \mathrm{~h}$ ), in keeping with reduced BAT mass and activity [40]. In humans, fat accumulation and distribution in obesity can be divided into those with central obesity (apple-shape), whereby subjects have a high waist-to-hip ratio (WHR), and peripheral obesity (pear-shaped, with a lower WHR) [48]; those with central obesity have a greater cardiometabolic risk $[49,50]$. Subjects with central obesity also have decreased ${ }^{18} \mathrm{~F}$-FDG uptake by BAT at room temperature [51] and UCP1 expression in human BAT negatively correlates with greater central/peripheral fat distribution [52]. These data suggest an association between BAT activity and WAT distribution, however, given that these data are correlative, it is not currently possible to determine if BAT regulation is driving altered WAT distribution or vice versa. BAT has also been implicated in altered BAT function in the increased cardiometabolic risk of central obesity (Figure 2). Cold-induced BAT activation in mice lowers triglyceride and cholesterol levels https:/ / www.nature.com/articles/s41591-020-1126-7-ref-CR1 (accessed on 21 April 2021), protecting mice from the development of atherosclerosis [53,54]. In humans, high BAT activity ( ${ }^{18} \mathrm{~F}$-FDG uptake during cold exposure) correlates with reduced cardiovascular risk factors and subsequent development of early markers of atherosclerosis [55], while a large retrospective study ( $>50,000$ PET CT scans) showed that the presence of BAT was associated with a lower prevalence of cardiometabolic disease particularly in obese subjects [56]. However, it remains unclear how BAT is mechanistically connected to cardiometabolic risk. Two possibilities are that (1) BAT may communicate with other organs to reduce metabolic risk via the secretion of batokines [57], and (2) BAT removes circulating glucose and lipids to improve cardiometabolic health. Alternatively, it is possible that genetic factors that are associated with BAT development and activity may also be associated with cardiometabolic disease. Further research is therefore required to determine any causative role of BAT in protecting against cardiometabolic disease.

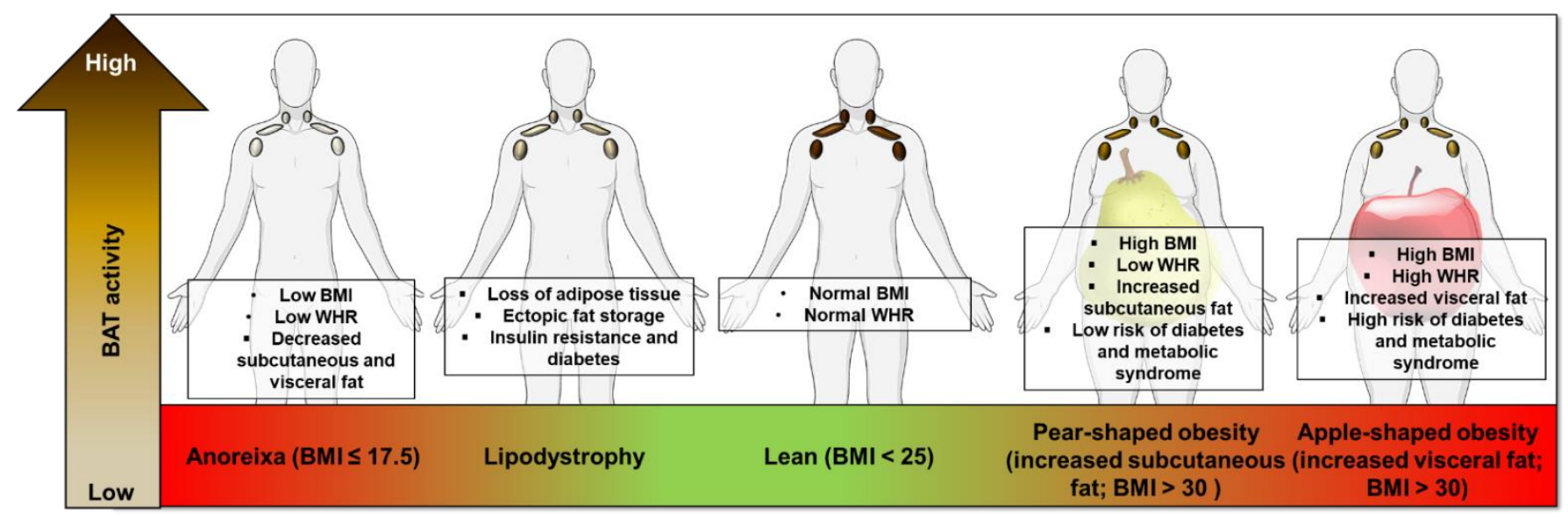

Figure 2. Summary of the impact of undernutrition, overnutrition and altered fat distribution on BAT function. BAT activity is decreased in disorders of both reduced and excessive WAT mass compared with normal weight individuals. Fat distribution may also regulate BAT function, for example central (apple-shaped) obesity may impair BAT activity to a greater extent than those with predominant peripheral (pear-shaped) obesity. In addition, lipodystrophy syndromes are associated with reduced BAT function. Brown adipose tissue (BAT), white adipose tissue (WAT), Body mass index (BMI), waist-hip-ratio (WHR).

While reduced BAT glucose uptake may be a measure of decreased thermogenesis, BAT is an insulin sensitive organ and early studies in rabbits showed that insulin infusion 
had a direct effect on glucose uptake by BAT during mild cold exposure $\left(20^{\circ} \mathrm{C}\right.$ for $48 \mathrm{~h}$ ) but had little effect on glucose uptake in warm conditions [58]. In humans, insulin enhanced ${ }^{18}$ F-FDG glucose uptake into BAT approximately five-fold during warm conditions (albeit to a lesser extent than during cold exposure at $17^{\circ} \mathrm{C}$ for $2 \mathrm{~h}$ ), although whether insulin activates human BAT thermogenesis is unclear [59]. ${ }^{18} \mathrm{~F}-\mathrm{FDG}$ uptake by BAT correlates with whole-body insulin sensitivity so BAT glucose uptake may reflect insulin resistance [60]. In T2DM subjects, despite reduced ${ }^{18} \mathrm{~F}-\mathrm{FDG}$ uptake by BAT these subjects had similar total EE and BAT oxidative metabolism compared to control subjects [47]. However, UCP1 expression in human BAT negatively correlates with glycated hemoglobin (HbA1c) [52]. Overall, these data suggest that whilst it is likely that BAT activity/volume is reduced in obesity and T2DM, importantly BAT retains functionality. In addition, repeated cold exposure $\left(\sim 15^{\circ} \mathrm{C}\right.$ for 10 days; $2 \mathrm{~h}$ on day $1,4 \mathrm{~h}$ on day 2 and $6 \mathrm{~h}$ on days $\left.3-10\right)$ increases ${ }^{18}$ F-FDG uptake by BAT in subjects with obesity and T2DM, suggesting either that BAT mass can be recruited or that dormant BAT can become functional [61,62]. This may represent a treatment to increase BAT activity and $\mathrm{EE}$, promote weight loss and improve metabolic health.

The distribution and volume of WAT contributes to ethnic differences in T2DM and cardiovascular disease [63-66], whereby the risk of T2DM is increased in Asian and black ethnic groups compared to Caucasians [67]. Differences in BAT volume and activity have been observed in different ethnic groups which could increase their susceptibility to obesity, T2DM and/or cardiovascular disease. For example, lean male Dutch national south Asians had $\sim 25 \%$ lower energy expenditure during warm conditions than age- and BMI-matched Caucasian participants, decreased BAT volumes (as measured by ${ }^{18} \mathrm{~F}-\mathrm{FDG}$ $\mathrm{PET} / \mathrm{CT}$ during $2 \mathrm{~h}$ cold exposure) and increased shivering thermogenesis [68]. Genetic studies have identified $U C P 1$ variants associated with nonshivering thermogenesis, while the UCP1 haplotype with the highest thermogenic efficiency was more commonly found in populations from colder habitats [69]. These data support the hypothesis of evolutionary regulation of BAT, where descendants from countries with the absence of extreme cold have reduced BAT volume and activity. Consequently, while individuals with south Asian or African heritage have an increased prevalence of obesity and T2DM it is possible that strategies to activate BAT would be less successful in these populations.

\subsection{Weight Loss and Caloric Restriction}

Similar to the effect of repeated cold exposure in obese subjects, weight loss $(\sim 29 \%$ weight loss following one year) following bariatric surgery increases ${ }^{18}$ F-FDG uptake by BAT [70], in keeping with recruitment of BAT. A more common, less invasive, method for weight loss is dietary calorie restriction (CR). $C R$ is defined as the reduction in energy intake below normal ad libitum levels without malnutrition or deprivation of essential nutrients. Rodent, primate and human studies have suggested that CR may delay the onset of age-related cardiovascular and neurodegenerative diseases and can induce the remission of T2DM [71-73]. The mechanisms through which CR decreases the risk of chronic disease in humans remains incompletely understood, primarily due to the lack of long-term studies [74]. In mice, 12-20 weeks of CR decreases metabolic rate, BAT mass and core body temperature [75-77], however, in rats, $40 \%$ CR for $\sim 6$ and 26 months caused BAT hypertrophy without altering Ucp1 gene expression [78]. Changes in BAT mass do not necessarily translate to BAT activity, and it is unclear if CR in lean animals has a beneficial effect on BAT activity. CR in mice induces the development of beige fat in subcutaneous and visceral adipose tissue which may be required to increase body temperature during feeding [79]. In humans, a two-phase dietary intervention (eight-week very low-calorie diet $\sim 780-1000 \mathrm{Kcal} /$ day and six-month weight maintenance) decreased thermogenic markers in abdominal WAT, although these markers were not measured in BAT [80]. Due to the limited data available the effects of CR on BAT activity in normal weight individuals is unknown, but in obese subjects, we speculate that CR may lead to the recruitment and activation of BAT, counteracting the reduced BAT mass observed in obesity. 


\subsection{Undernutrition and Lipodystrophy}

There is also evidence that BAT activity is dysregulated in underweight individuals. Anorexia nervosa (AN) is an eating disorder of chronic starvation causing severe depletion of body fat and fat-free mass (Figure 2). Women with AN (either current or recovered) may have a lower prevalence of ${ }^{18} \mathrm{~F}$-FDG uptake by BAT during cold exposure (using a cooling vest at $17^{\circ} \mathrm{C}$ for $2 \mathrm{~h}$ ) compared with normal weight controls, in keeping with reduced BAT activity although the sample size was small [81]. Defects in skeletal muscle thermogenesis have also been identified in AN patients [82]. A retrospective analysis of over 15,000 ${ }^{18}$ F-FDG PET/CT cases identified reduced BAT activation in underweight patients (BMI $<16 \mathrm{~kg} / \mathrm{m}^{2}$ ), while those with a BMI between $18-21 \mathrm{~kg} / \mathrm{m}^{2}$ had the greatest ${ }^{18}$ F-FDG uptake [83]. Young patients with constitutional leanness (mean BMI $\sim 16 \mathrm{~kg} / \mathrm{m}^{2}$ ), but not AN patients, demonstrate ${ }^{18} \mathrm{~F}-\mathrm{FDG}$ uptake by BAT [84], potentially suggesting that AN reduces BAT activity rather than a low BMI per se. However, due to the lack of histological analysis it is possible than AN subjects do have BAT, albeit inactive.

Another group of disorders with substantial reductions in fat mass are the lipodystrophy syndromes, these patients may have fat loss throughout the entire body (congenital generalized lipodystrophy; CGL) or in discrete regions (familial partial lipodystrophy; FPLD) [85]. Lipodystrophy syndromes are associated with insulin resistance, diabetes, dyslipidemia, kidney disease and nonalcoholic fatty liver disease and there is also evidence of dysregulated BAT activity (Figure 2). CGL type 2 (CGL2) is caused by mutations in the Berardinelli-Seip congenital lipodystrophy 2 gene (BSCL2) [86]. BSCL2 is more highly expressed in murine BAT than other adipose depots, highlighting a potentially important role in thermogenesis [87]. BSCL2 is essential for acute and chronic cold-induced BAT activation in mice and prevents BAT necroptosis [88], it is unknown though whether BAT activity is altered in patients with CGL2. However, BAT activity may be decreased in patients with type 2 familial partial lipodystrophy (FPLD2), whereby cold exposure ( $2 \mathrm{~h}$ intermittent feet immersion, $5 \mathrm{~min}$ in $/ 5 \mathrm{~min}$ out in cold water at $\sim 4{ }^{\circ} \mathrm{C}$ ) did not result in ${ }^{18}$ F-FDG uptake by BAT and differentiated pre-adipocytes obtained from the supraclavicular BAT depots had lower UCP1 levels than control subjects [89]. These data suggest that BAT activity is reduced in lipodystrophy patients and that specific mutations that result in lipodystrophies have direct effects on brown adipocyte function. Further investigation into diseases of adipose distribution in the human may also provide unique insights as to how specific WAT depots influence BAT mass and thermogenesis.

\section{Dietary Components That Alter BAT Thermogenesis}

While overnutrition and undernutrition regulate BAT activity, dietary composition also has an important effect on BAT function. Understanding how dietary components alter BAT mass and activation may identify targets for therapeutic manipulation without the need to develop pharmacological agents [90].

\subsection{Diet-Induced Thermogenesis}

The increase in EE above the basal metabolic rate in response to food intake is referred to as diet-induced thermogenesis (DIT). Thermogenesis following a meal is divided into (1) obligatory thermogenesis and (2) facultative thermogenesis. Obligatory thermogenesis is the necessary accompaniment of all metabolic processes including digestion, absorption and storage of ingested nutrients; whereas facultative thermogenesis is regulated by hypothalamic centers and is the increase in EE in response to dietary intake which varies with food composition and volume of food, which we refer to as DIT [91]. In rodents, DIT has been suggested for four decades, whereby a cafeteria diet increased EE and interscapular skin temperature [23] and a single low-protein high-carbohydrate meal increased BAT respiration [92]. However, other studies found no increase in BAT thermogenesis in rats fed a cafeteria diet [93] or a low-carbohydrate, high-fat diet (HFD) [94]. DIT in adult humans accounts for $5-15 \%$ of daily EE [95] and recent work has identified that BAT contributes to DIT, as evidenced by increased BAT oxygen consumption and blood flow following 
a mixed high-carbohydrate meal. In fact, BAT activity was increased to the same extent as seen during a cold stress ( $2 \mathrm{~h}$, individualized cooling protocol) [96]. In addition, BATpositive individuals have higher DIT compared with BAT-negative subjects [97]. The acute effects of DIT observed in both animals and humans in response to a meal composed of varying macronutrient content is likely to differ when administered chronically. In obese children (mean BMI $\sim 26 \mathrm{~kg} / \mathrm{m}^{2}$, aged $\sim 10$ years) a high fat meal ( $48 \%$ fat) resulted in lower thermogenesis (measured by indirect calorimetry) compared to an isocaloric and isoproteic low-fat meal [98]. Furthermore, rodents maintained on a HFD have decreased BAT energy consumption and accumulate WAT $[99,100]$.

\subsection{Macronutrient Content of Meals}

Some of the conflicting data from rodent studies investigating DIT may be due to the specific macronutrient content of the meals as this may alter post-prandial BAT thermogenesis. Here we will provide an overview of the effects of individual macronutrients and bioactive compounds on BAT function.

\subsubsection{Carbohydrate}

In rats, a low-protein, high-carbohydrate diet (74\% carbohydrate, $6 \%$ protein) for 15 days increased basal and noradrenaline-stimulated thermogenesis and increased Ucp 1 gene expression in BAT by $60 \%$ compared to rats fed an isocaloric diet containing $63 \%$ carbohydrate and $17 \%$ protein, suggesting increased BAT activity [101]. There are no studies investigating the effect of dose-dependent carbohydrate diets on BAT function in humans, however, indirect evidence suggests that carbohydrate likely increases BAT thermogenesis. Two independent studies demonstrated that a single carbohydrate rich meal (78\% $1622 \mathrm{kcal}$ and 58\% $542 \mathrm{kcal}$ carbohydrate, respectively) stimulated BAT ${ }^{18}$ F-FDG uptake at room temperature [96,102] and increased BAT oxidative metabolism [96]. In addition, carbohydrate consumption stimulates insulin secretion and insulin increases glucose uptake by BAT [59]. Insulin has direct effects on the sympathetic nervous system and increases BAT activity and thermogenesis $[103,104]$. It is therefore possible that dietary carbohydrate may acutely increase BAT activity in part via insulin secretion.

\subsubsection{Fat}

In rodents, HFDs of different fat content and duration increase Ucp1 mRNA and protein expression in BAT [105]. However, not all dietary fats elicit identical responses in BAT. In rats, supplementation of different $\mathrm{C} 18$ fatty acids for seven days failed to increase Ucp1 mRNA expression in BAT despite inducing weight loss, although 2-hydroxyoleic acid increased Ucp1 mRNA expression in WAT [106], potentially in keeping with browning of WAT. Fat-induced activation of BAT thermogenesis may be mediated by cholecystokininactivation (CCK) which is a satiety hormone secreted by the I-cells of the upper small intestine following the consumption of both fat and protein [107]. CCK activates sympathetic nerves in BAT, increasing BAT thermogenesis in rats $[108,109]$ through activation of the CCKA receptor [110].

Few studies in humans have investigated the effect of dietary fat on adipose thermogenesis. Eicosapentaenoic acid (an omega-3 fatty acid) increases UCP1 expression in white abdominal and mammary differentiated pre-adipocytes obtained from lean women, but this effect was not investigated in brown adipocytes [111]. Human BAT does utilize dietary fatty acids (DFA) as demonstrated by oral ${ }^{18} \mathrm{~F}$-FTHA administration during $4 \mathrm{~h}$ cold exposure in (using a water-cooled suit at $\sim 18.0^{\circ} \mathrm{C}$ ) [112]. However, ${ }^{18}$ FTHA uptake by BAT was not increased following a four-week cold acclimation protocol and BAT only accounts for a small proportion $(<1 \%)$ of total body DFA clearance [112] and whether these DFAs stimulate thermogenesis at room temperature is unknown. 


\subsubsection{Protein}

In rodents a single low-protein high-carbohydrate meal increases $\left[{ }^{3} \mathrm{H}\right]$ norepinephrine $\left(\left[{ }^{3} \mathrm{H}\right]-\mathrm{NE}\right)$ turnover in BAT [113] and long-term high protein diets (8-16 weeks; $51-70 \%$ protein) increase BAT Ucp1 gene expression and decrease body weight compared to diets with lower protein/carbohydrate ratios [114-118]. However, the specific dietary protein may also play a crucial role in the regulation of BAT function [119]. In humans, increasing dietary protein whilst maintaining a constant carbohydrate intake reduces ad libitum caloric intake [120]. High protein diets are thought to alter energy balance through DIT related satiety [121], aiding weight loss by reducing energy efficiency through increased thermogenesis [95]. However, to date no one has explored the effect of protein on BAT activity and the effect of high protein diets on weight loss in humans is not conclusive [120,122].

\subsection{Dietary Bioactive Compounds \\ 4.3.1. Capsaicin and Capsinoids}

One of the most extensively studied dietary components involved in BAT activation are capsaicin and capsinoids which are found in chili peppers and are potent activators of the capsaicin receptor (transient receptor potential vanilloid 1; TRPV1) [123]. TPRV1 is involved in body temperature regulation in rodents, primates and humans [124,125], and TRPV1 activation has been shown to both increase [126] and decrease [127] BAT thermogenesis. In rats, intravenous injection of the TRPV1 agonist dihydrocapsaicin reduced BAT sympathetic nerve activity, thermogenesis and core body temperature [128]. Contrary to these findings, capsaicin stimulated TRPV1 activation in WAT and induced inguinal beiging in mice [129]. Capsinoids represent a more appropriate supplement in humans due to their nonpungent nature. In mice, capsinoid administration increases BAT temperature, whole body oxygen consumption and fat oxidation, mediated through Trpv1 [130]. In humans, during cold exposure ( $19{ }^{\circ} \mathrm{C}$ for $2 \mathrm{~h}$, feet placed on an ice block), a single dose of oral capsinoids ( $9 \mathrm{mg}$ ) increased ${ }^{18} \mathrm{~F}-\mathrm{FDG}$ uptake by BAT without altering supraclavicular skin temperature [131]. It remains unclear if capsinoid supplementation alone would be an effective strategy to activate/recruit BAT in adult humans. In one study, a single dose of capsinoids (12 mg) only increased EE in BAT-positive subjects during acute cold exposure $\left(\sim 14.5^{\circ} \mathrm{C}\right.$ for $\left.2 \mathrm{~h}\right)$ [132]. However, six weeks of daily capsinoids $(9 \mathrm{mg})$ ingestion increased cold induced thermogenesis (CIT, $19^{\circ} \mathrm{C}$ for $2 \mathrm{~h}$ ) in healthy subjects with low BAT activity, suggesting that long-term capsinoid ingestion may increase BAT mass even in subjects with minimal BAT [133]. A combination of capsinoid supplementation and mild cold exposure may be an effective strategy for recruitment and activation of BAT in humans, but it remains unclear whether capsinoids will induce improvements in other metabolic parameters such as insulin sensitivity as observed during cold exposure.

\subsubsection{Tea, Caffeine and Catechins}

Catechins are natural phenols with antioxidant activity [134]. A meta-analysis determined that daily catechin-caffeine tea ingestion in humans increased daily EE (by $5 \%$ ) and whole-body fat-oxidation [135]. In humans, a single acute oral catechin/caffeine beverage (615 mg catechin and $77 \mathrm{mg}$ caffeine) increased whole body EE at a thermoneutral temperature $\left(27^{\circ} \mathrm{C}\right)$ only in BAT-positive subjects, assessed by ${ }^{18} \mathrm{~F}$-FDG PET/CT, compared to placebo (0 mg catechin and $81 \mathrm{mg}$ caffeine), suggesting that catechin activates BAT in humans [136]. Furthermore, once daily ingestion of this catechin beverage for five weeks increased CIT (at $19^{\circ} \mathrm{C}$ for $2 \mathrm{~h}$, intermittently feet placed on an ice block) in individuals with minimal BAT, suggesting either that daily ingestion of catechin may recruit BAT or enhance CIT in other tissues such as skeletal muscle [136]. Administration of catechin (540 mg/day) for 12 weeks in a double-blind study in women increased BAT density by nearly $20 \%$ measured by near-infrared time-resolved spectroscopy (a marker of BAT activity) $[137,138]$. It will be important to investigate the effect of long-term daily catechincaffeine tea supplementation on body weight and metabolic parameters to determine the utility of this approach. 


\subsubsection{Menthol}

Menthol is a compound found in mint and is an activator of the calcium-permeable cation channel, transient receptor potential melastatin 8 (TRPM8) $[139,140]$. TRMP8 is expressed in sensory nerves in the skin, senses cold temperature and functions as a ligandgated channel to menthol, inducing a cold sensation [141]. TRPM8 is expressed in murine BAT and activation by menthol increases BAT Ucp1 mRNA and protein expression [142]. In vitro, menthol increased UCP1 expression in human white adipocytes [143] and in vivo transdermal menthol administration increased total EE over a $7 \mathrm{~h}$ period by indirect calorimetry [144]. Further studies in humans are required to assess if menthol increases BAT activity or whether the activation of TRPM8 via menthol or alternative agonists [145] offers therapeutic potential in the treatment of obesity.

\subsubsection{Other Dietary Compounds}

Many other dietary compounds have been identified in rodent studies to influence BAT thermogenesis and WAT browning, these include conjugated linoleic acid [146], casein protein [119], curcumin [147,148], garlic powder [149], procyanidin-rich extracts from black soybean seed [150], resveratrol [151] and extracts from ginger family plants [152,153] amongst others [154,155] (reviewed in [156]). While these data are from rodent studies, human studies have also identified dietary compounds with thermogenic potential (Figure 3). Amongst these dietary compounds is cinnamaldehyde (found in cinnamon), which increases EE and postprandial fat oxidation in vivo [157] and increases UCP1 expression in human white adipocytes [158]. Given that oral cinnamaldehyde is well tolerated, cinnamon consumption may be a simple yet effective way to activate thermogenesis. In addition to cinnamaldehyde, acute oral administration of $2.5 \mathrm{mg} / \mathrm{kg}$ ephedrine (the active component of the herb Ephedra, a direct and indirect sympathomimetic amine) to lean and obese subjects increased ${ }^{18}$ F-FDG uptake by BAT at room temperature [159]. However, it is unlikely that the ephedrine could be used in the clinical setting due to off target effects such as tachycardia and arrhythmias.

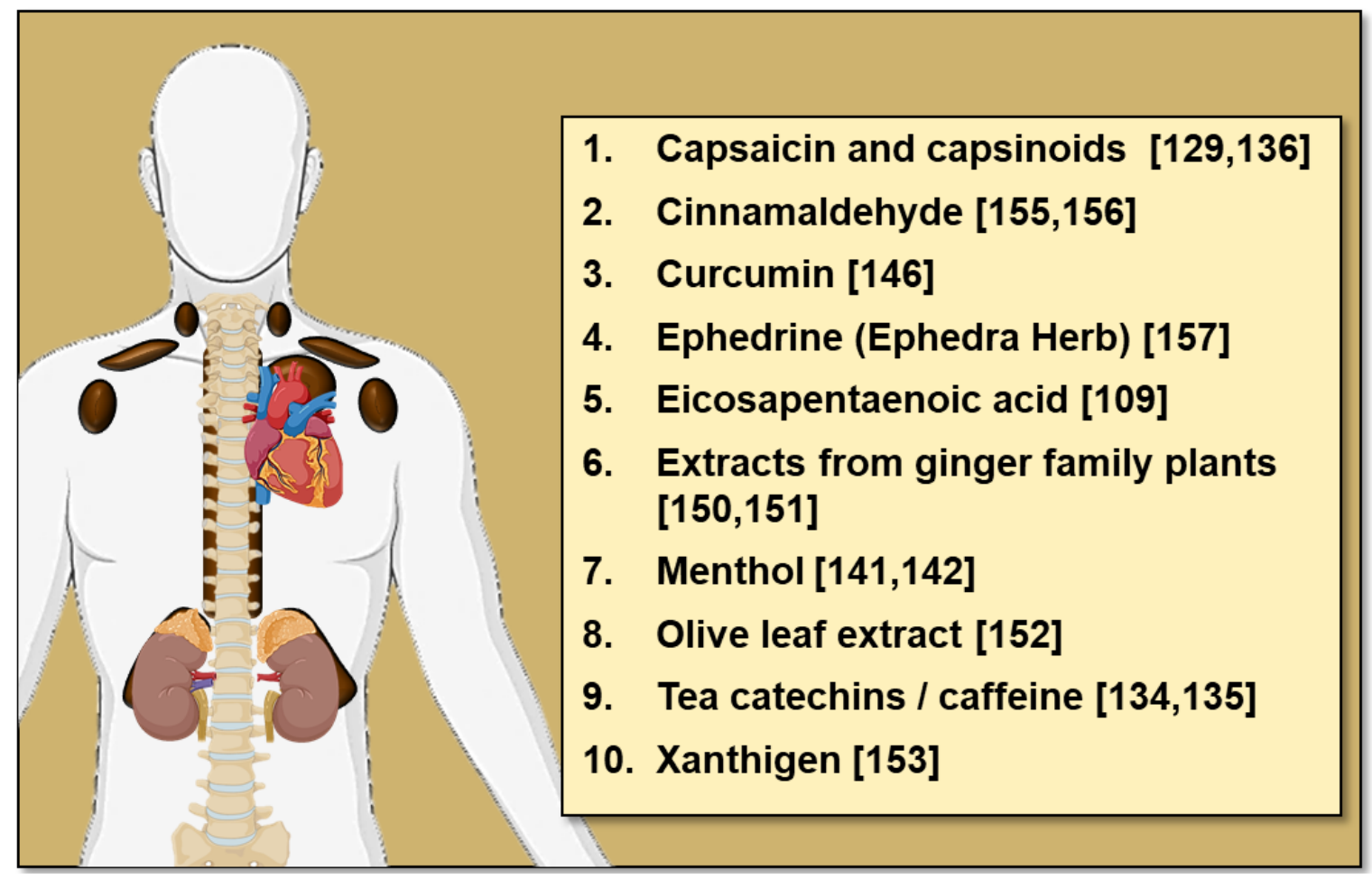

Figure 3. Dietary compounds with thermogenic potential in humans. 


\subsubsection{Safety of Dietary Approaches to Activate BAT}

Macronutrient and bioactive compound supplementation approaches to increase BAT volume could be effective, safe and widely available, and may represent a more holistic clinical strategy for long-term weight loss/maintenance and improved cardiometabolic health. Chronic alteration of macronutrient content is a more complicated strategy and the safety and long-term effects of high fat, protein or carbohydrate diets in humans is not yet fully understood, particularly as the quality of macronutrients is of crucial importance [160]. Strategies may have to differ in certain patient groups such as those with T2DM, however, high-protein diets $(\sim 30 \%)$ and ketogenic diets have beneficial effects on weight loss and lipid metabolism which is of benefit to T2DM patients [161-163]. The long-term safety of the bioactive compounds discussed in this review have not yet been studied in humans, this will be crucial in order to support therapeutic administration.

Briefly, while capsaicin is a potent irritant and can cause pain, sweating and chest pain $[123,164,165]$, capsinoids are well tolerated in healthy humans, eliciting no change in blood pressure or heart rate [166,167]. Bioactive compounds such as tea catechins have been associated with hepatotoxicity [168], therefore their long-term safety must be investigated [169]. Small quantities of cinnamon have been used to flavor food for centuries with no reports of side effects. The suggested daily intake of the active ingredient of cinnamon, cinnamaldehyde is $1.25 \mathrm{mg} / \mathrm{kg}$ and the acute and long-term toxicity is low at nutritional doses [170]. Non-nutritional doses of cinnamaldehyde may cause skin irritation [171] and hepatotoxicity [172].

Therefore, the potential beneficial and detrimental effects of long-term dietary manipulation and supplementation must be studied in patients where increasing BAT mass and activity is of potential therapeutic benefit (e.g. those with obesity and T2DM).

\section{The Effect of Exercise on BAT Activity}

Physical activity is another important component of EE with beneficial effects, as exercise improves cardiovascular health and offers protection against obesity, T2DM and metabolic diseases by the improvement of insulin sensitivity, increased WAT mitochondrial activity, glucose tolerance and the reduction in circulating lipids [173].

Several studies have examined the interplay between exercise and BAT thermogenesis. Activation of BAT and exercise both raise core body temperature [174], while exercise also induces sympathetic activation but with the purpose of increasing cardiac output and blood flow to active skeletal muscles. Exercise can both increase [175,176] and decrease [177] BAT thermogenesis in rodents (reviewed in [178]). It remains unclear why animal studies show contradictory results, however, rodent exercise studies have used different training regimes (both type and duration) to investigate the effect of exercise on BAT function.

In humans, exercise more consistently decreases BAT activity. Endurance athletes have reduced cold-induced ${ }^{18} \mathrm{~F}$-FDG uptake by BAT compared to sedentary controls, without induction of UCP1 expression in subcutaneous abdominal adipose tissue, also suggesting a lack of adipose tissue browning [179]. Short term high- and moderate-intensity interval training also decreased insulin-stimulated ${ }^{18}$ F-FDG uptake by BAT [180], but exercise increases glucose uptake by skeletal muscle [181]. It is possible that exercise increases skeletal muscle thermogenesis, reducing the need for BAT to maintain body temperature in humans with resultant regression of BAT mass, however, this is yet to be determined.

There has also been recent interest in the secretion of myokines that can increase adipose thermogenesis. In rodents, exercise results in the beiging of WAT, resulting in increased multilocular lipid droplets and upregulation of thermogenic genes (e.g., Ucp1, Prdm16) [182,183] in response to the secretion of myokines such as irisin and meteorin-like $[184,185]$. However, in humans, exercise does not increase plasma irisin or induce browning in normoglycemic, pre-diabetic, sedentary or endurance trained subjects $[179,186]$. These data suggest that, at least in humans, exercise-induced release of factors from skeletal muscle does not enhance BAT thermogenesis. However, BAT has a role regulating skeletal adaptations, for example exercise induces release of 12,13-diHOME 
by BAT in both rodents and humans and activates fatty acid uptake and oxidation in skeletal muscle [187]. Further work is required to determine the interplay between BAT and skeletal muscle in the regulation of thermogenesis.

\section{Perspective}

From the pioneering recognition of BAT in nutritional energetics in the late 1970's [23,24] to the identification of functional UCP1 positive BAT in adult humans over a decade ago [4-6,32,188], our understanding of BAT has evolved immeasurably. In vitro and animal studies have made extraordinary contributions to unravelling the physiology of BAT in conditions of weight loss and gain and the effect of dietary composition and individual dietary components on BAT activity. Rodent studies using ${ }^{18} \mathrm{~F}-\mathrm{FDG}$ and other PET tracers have yet to be employed to directly measure nutritional uptake by BAT and BAT thermogenesis in response to varying macronutrients or individual bioactive compounds. These studies will be helpful to guide dedicated human studies in both males and females [189] to determine the best candidates with thermogenic potential.

To date, evidence from dietary studies in mice and humans have produced some conflicting results and it remains unclear whether dietary components and bioactive compounds have direct effects on BAT thermogenesis. Human BAT shows dysregulation in altered nutritional states such as during caloric excess (obesity) or caloric deficiency (anorexia). Furthermore, there is direct nutritional regulation of BAT activity from both macronutrients, dietary components and bioactive compounds, some of which alter EE. It remains to be determined if the nutritional activation of BAT may have therapeutic potential over chronic administration, or if such treatments would result in weight loss or improve metabolic health. Studies to investigate the effect of varying the macronutrient composition in humans are required in order to determine the role of BAT in DIT but are complex to undertake. It will also be important to undertake dedicated human studies in both males and females and in those of different ethnic origins to determine the candidates with the widest thermogenic potential.

Despite these challenges, nutritional interventions may represent a useful nonpharmacological means to enhance BAT mass and activity and warrant extended investigation. Further research will determine if individual or a combination of compounds could be used as a safe clinical strategy for long-term weight loss/maintenance and improved metabolic health.

Author Contributions: Conceptualization, K.J.S. and R.H.S.; writing—original draft preparation: K.J.S. and R.H.S.; writing—review and editing, K.J.S. and R.H.S.; funding acquisition; R.H.S. All authors have read and agreed to the published version of the manuscript.

Funding: This research was funded by grants from the Medical Research Council (MR/K010271/1; MR/S035761/1) and The Chief Scientist Office of the Scottish Government (SCAF/17/02).

Institutional Review Board Statement: Not applicable.

Informed Consent Statement: Not applicable.

Data Availability Statement: Not applicable.

Conflicts of Interest: The authors declare no conflict of interests.

\section{References}

1. Public-Health-England. Health Matters: Obesity and the Food Environment. Available online: https://www.gov. uk/government/publications/health-matters-obesity-and-the-food-environment/health-matters-obesity-and-the-foodenvironment--2 (accessed on 5 May 2020).

2. Vass, A. Obesity causes 30,000 deaths a year, report says. Br. Med. J. 2002, 324, 192. [CrossRef]

3. Douglas, I.J.; Bhaskaran, K.; Batterham, R.L.; Smeeth, L. The effectiveness of pharmaceutical interventions for obesity: Weight loss with orlistat and sibutramine in a United Kingdom population-based cohort. Br. J. Clin. Pharmacol. 2015, 79, 1020-1027. [CrossRef] 
4. Cypess, A.M.; Lehman, S.; Williams, G.; Tal, I.; Rodman, D.; Goldfine, A.B.; Kuo, F.C.; Palmer, E.L.; Tseng, Y.H.; Doria, A.; et al. Identification and importance of brown adipose tissue in adult humans. N. Engl. J. Med. 2009, 360, 1509-1517. [CrossRef]

5. Van Marken Lichtenbelt, W.D.; Vanhommerig, J.W.; Smulders, N.M.; Drossaerts, J.M.; Kemerink, G.J.; Bouvy, N.D.; Schrauwen, P.; Teule, G.J. Cold-activated brown adipose tissue in healthy men. N. Engl. J. Med. 2009, 360, 1500-1508. [CrossRef]

6. Virtanen, K.A.; Lidell, M.E.; Orava, J.; Heglind, M.; Westergren, R.; Niemi, T.; Taittonen, M.; Laine, J.; Savisto, N.J.; Enerback, S.; et al. Functional brown adipose tissue in healthy adults. N. Engl. J. Med. 2009, 360, 1518-1525. [CrossRef]

7. Lidell, M.E. Brown Adipose Tissue in Human Infants. Handb. Exp. Pharmacol. 2019, 251, 107-123. [CrossRef]

8. Dawkins, M.J.R.; Hull, D. The Production of Heat by Fat. Sci. Am. 1965, 213, 62-69. [CrossRef]

9. Sacks, H.; Symonds, M.E. Anatomical locations of human brown adipose tissue: Functional relevance and implications in obesity and type 2 diabetes. Diabetes 2013, 62, 1783-1790. [CrossRef]

10. Lidell, M.E.; Betz, M.J.; Dahlqvist Leinhard, O.; Heglind, M.; Elander, L.; Slawik, M.; Mussack, T.; Nilsson, D.; Romu, T.; Nuutila, P.; et al. Evidence for two types of brown adipose tissue in humans. Nat. Med. 2013, 19, 631-634. [CrossRef]

11. Zhang, F.; Hao, G.; Shao, M.; Nham, K.; An, Y.; Wang, Q.; Zhu, Y.; Kusminski, C.M.; Hassan, G.; Gupta, R.K.; et al. An Adipose Tissue Atlas: An Image-Guided Identification of Human-like BAT and Beige Depots in Rodents. Cell Metab. 2018, 27, 252-262.e3. [CrossRef]

12. Coelho, M.; Oliveira, T.; Fernandes, R. Biochemistry of adipose tissue: An endocrine organ. Arch. Med. Sci. 2013, 9, 191-200. [CrossRef]

13. Cannon, B.; Nedergaard, J. Brown adipose tissue: Function and physiological significance. Physiol. Rev. 2004, 84, 277-359. [CrossRef]

14. Blondin, D.P.; Nielsen, S.; Kuipers, E.N.; Severinsen, M.C.; Jensen, V.H.; Miard, S.; Jespersen, N.Z.; Kooijman, S.; Boon, M.R.; Fortin, M.; et al. Human Brown Adipocyte Thermogenesis Is Driven by ß2-AR Stimulation. Cell Metab. 2020, 32, 287-300.e7. [CrossRef] [PubMed]

15. Riis-Vestergaard, M.J.; Richelsen, B.; Bruun, J.M.; Li, W.; Hansen, J.B.; Pedersen, S.B. Beta-1 and Not Beta-3 Adrenergic Receptors May Be the Primary Regulator of Human Brown Adipocyte Metabolism. J. Clin. Endocrinol. Metab. 2019, 105, e994-e1005. [CrossRef] [PubMed]

16. Cypess, A.M.; Weiner, L.S.; Roberts-Toler, C.; Franquet Elía, E.; Kessler, S.H.; Kahn, P.A.; English, J.; Chatman, K.; Trauger, S.A.; Doria, A.; et al. Activation of human brown adipose tissue by a $\beta 3$-adrenergic receptor agonist. Cell Metab. 2015, $21,33-38$. [CrossRef]

17. McNeill, B.T.; Morton, N.M.; Stimson, R.H. Substrate Utilization by Brown Adipose Tissue: What's Hot and What's Not? Front. Endocrinol. 2020, 11, 571659. [CrossRef]

18. Wu, J.; Boström, P.; Sparks, L.M.; Ye, L.; Choi, J.H.; Giang, A.-H.; Khandekar, M.; Virtanen, K.A.; Nuutila, P.; Schaart, G.; et al. Beige adipocytes are a distinct type of thermogenic fat cell in mouse and human. Cell 2012, 150, 366-376. [CrossRef]

19. Labbé, S.M.; Caron, A.; Chechi, K.; Laplante, M.; Lecomte, R.; Richard, D. Metabolic activity of brown, "beige," and white adipose tissues in response to chronic adrenergic stimulation in male mice. Am. J. Physiol. Endocrinol. Metab. 2016, 311, E260-E268. [CrossRef]

20. Feldmann, H.M.; Golozoubova, V.; Cannon, B.; Nedergaard, J. UCP1 ablation induces obesity and abolishes diet-induced thermogenesis in mice exempt from thermal stress by living at thermoneutrality. Cell Metab. 2009, 9, 203-209. [CrossRef]

21. Lowell, B.B.; S-Susulic, V.; Hamann, A.; Lawitts, J.A.; Himms-Hagen, J.; Boyer, B.B.; Kozak, L.P.; Flier, J.S. Development of obesity in transgenic mice after genetic ablation of brown adipose tissue. Nature 1993, 366, 740-742. [CrossRef]

22. Enerbäck, S.; Jacobsson, A.; Simpson, E.M.; Guerra, C.; Yamashita, H.; Harper, M.E.; Kozak, L.P. Mice lacking mitochondrial uncoupling protein are cold-sensitive but not obese. Nature 1997, 387, 90-94. [CrossRef] [PubMed]

23. Rothwell, N.J.; Stock, M.J. A role for brown adipose tissue in diet-induced thermogenesis. Nature 1979, 281, 31-35. [CrossRef] [PubMed]

24. Himms-Hagen, J.; Desautels, M. A mitochondrial defect in brown adipose tissue of the obese (ob/ob) mouse: Reduced binding of purine nucleotides and a failure to respond to cold by an increase in binding. Biochem. Biophys. Res. Commun. 1978, 83, 628-634. [CrossRef]

25. Commins, S.P.; Watson, P.M.; Padgett, M.A.; Dudley, A.; Argyropoulos, G.; Gettys, T.W. Induction of Uncoupling Protein Expression in Brown and White Adipose Tissue by Leptin. Endocrinology 1999, 140, 292-300. [CrossRef] [PubMed]

26. Heaton, J.M. The distribution of brown adipose tissue in the human. J. Anat. 1972, 112, 35-39. [PubMed]

27. Cohade, C.; Mourtzikos, K.A.; Wahl, R.L. "USA-Fat": Prevalence is related to ambient outdoor temperature-evaluation with 18F-FDG PET/CT. J. Nucl. Med. 2003, 44, 1267-1270. [PubMed]

28. Nedergaard, J.; Bengtsson, T.; Cannon, B. Unexpected evidence for active brown adipose tissue in adult humans. Am. J. Physiol. Endocrinol. Metab. 2007, 293, E444-E452. [CrossRef]

29. Wei, H.; Chiba, S.; Moriwaki, C.; Kitamura, H.; Ina, K.; Aosa, T.; Tomonari, K.; Gotoh, K.; Masaki, T.; Katsuragi, I.; et al. A Clinical Approach to Brown Adipose Tissue in the Para-Aortic Area of the Human Thorax. PLoS ONE 2015, 10, e0122594. [CrossRef] [PubMed]

30. Jung, S.M.; Sanchez-Gurmaches, J.; Guertin, D. Brown Adipose Tissue Development and Metabolism. Handb. Exp. Pharmacol. 2019, 251, 3-36. 
31. Jespersen, N.Z.; Feizi, A.; Andersen, E.S.; Heywood, S.; Hattel, H.B.; Daugaard, S.; Peijs, L.; Bagi, P.; Feldt-Rasmussen, B.; Schultz, H.S.; et al. Heterogeneity in the perirenal region of humans suggests presence of dormant brown adipose tissue that contains brown fat precursor cells. Mol. Metab. 2019, 24, 30-43. [CrossRef]

32. Saito, M.; Okamatsu-Ogura, Y.; Matsushita, M.; Watanabe, K.; Yoneshiro, T.; Nio-Kobayashi, J.; Iwanaga, T.; Miyagawa, M.; Kameya, T.; Nakada, K.; et al. High incidence of metabolically active brown adipose tissue in healthy adult humans: Effects of cold exposure and adiposity. Diabetes 2009, 58, 1526-1531. [CrossRef]

33. Lee, P.; Smith, S.; Linderman, J.; Courville, A.B.; Brychta, R.J.; Dieckmann, W.; Werner, C.D.; Chen, K.Y.; Celi, F.S. Temperatureacclimated brown adipose tissue modulates insulin sensitivity in humans. Diabetes 2014, 63, 3686-3698. [CrossRef]

34. Chondronikola, M.; Volpi, E.; Borsheim, E.; Porter, C.; Saraf, M.K.; Annamalai, P.; Yfanti, C.; Chao, T.; Wong, D.; Shinoda, K.; et al. Brown Adipose Tissue Activation Is Linked to Distinct Systemic Effects on Lipid Metabolism in Humans. Cell Metab. 2016, 23, 1200-1206. [CrossRef]

35. Ouellet, V.; Labbe, S.M.; Blondin, D.P.; Phoenix, S.; Guerin, B.; Haman, F.; Turcotte, E.E.; Richard, D.; Carpentier, A.C. Brown adipose tissue oxidative metabolism contributes to energy expenditure during acute cold exposure in humans. J. Clin. Investig. 2012, 122, 545-552. [CrossRef]

36. Ramage, L.E.; Akyol, M.; Fletcher, A.M.; Forsythe, J.; Nixon, M.; Carter, R.N.; van Beek, E.J.; Morton, N.M.; Walker, B.R.; Stimson, R.H. Glucocorticoids Acutely Increase Brown Adipose Tissue Activity in Humans, Revealing Species-Specific Differences in UCP-1 Regulation. Cell Metab. 2016, 24, 130-141. [CrossRef]

37. Andersson, J.; Lundström, E.; Engström, M.; Lubberink, M.; Ahlström, H.; Kullberg, J. Estimating the cold-induced brown adipose tissue glucose uptake rate measured by 18F-FDG PET using infrared thermography and water-fat separated MRI. Sci. Rep. 2019, 9, 12358. [CrossRef]

38. Crandall, J.P.; Gajwani, P.; Jo, H.O.; Mawhinney, D.D.; Sterzer, F.; Wahl, R.L. Repeatability of brown adipose tissue measurements on FDG PET/CT following a simple cooling procedure for BAT activation. PLoS ONE 2019, 14, e0214765. [CrossRef]

39. Weir, G.; Ramage, L.E.; Akyol, M.; Rhodes, J.K.; Kyle, C.J.; Fletcher, A.M.; Craven, T.H.; Wakelin, S.J.; Drake, A.J.; Gregoriades, M.L.; et al. Substantial Metabolic Activity of Human Brown Adipose Tissue during Warm Conditions and Cold-Induced Lipolysis of Local Triglycerides. Cell Metab. 2018, 27, 1348-1355.e4. [CrossRef]

40. Saari, T.J.; Raiko, J.; U-Din, M.; Niemi, T.; Taittonen, M.; Laine, J.; Savisto, N.; Haaparanta-Solin, M.; Nuutila, P.; Virtanen, K.A. Basal and cold-induced fatty acid uptake of human brown adipose tissue is impaired in obesity. Sci. Rep. 2020, 10, 14373. [CrossRef]

41. Gariani, K.; Gariani, J.; Amzalag, G.; Delattre, B.M.; Ratib, O.; Garibotto, V. Hybrid PET/MRI as a tool to detect brown adipose tissue: Proof of principle. Obes. Res. Clin. Pract. 2015, 9, 613-617. [CrossRef]

42. Deng, J.; Neff, L.M.; Rubert, N.C.; Zhang, B.; Shore, R.M.; Samet, J.D.; Nelson, P.C.; Landsberg, L. MRI characterization of brown adipose tissue under thermal challenges in normal weight, overweight, and obese young men. J. Magn. Reason. Imaging 2018, 47, 936-947. [CrossRef]

43. Koskensalo, K.; Raiko, J.; Saari, T.; Saunavaara, V.; Eskola, O.; Nuutila, P.; Saunavaara, J.; Parkkola, R.; Virtanen, K.A. Human Brown Adipose Tissue Temperature and Fat Fraction Are Related to Its Metabolic Activity. J. Clin. Endocrinol. Metab. 2017, 102, 1200-1207. [CrossRef] [PubMed]

44. Sun, L.; Verma, S.; Michael, N.; Chan, S.P.; Yan, J.; Sadananthan, S.A.; Camps, S.G.; Goh, H.J.; Govindharajulu, P.; Totman, J.; et al. Brown Adipose Tissue: Multimodality Evaluation by PET, MRI, Infrared Thermography, and Whole-Body Calorimetry (TACTICAL-II). Obesity 2019, 27, 1434-1442. [CrossRef]

45. Karlas, A.; Reber, J.; Liapis, E.; Paul-Yuan, K.; Ntziachristos, V. Multispectral Optoacoustic Tomography of Brown Adipose Tissue. Handb. Exp. Pharmacol. 2019, 251, 325-336. [CrossRef]

46. Ouellet, V.; Routhier-Labadie, A.; Bellemare, W.; Lakhal-Chaieb, L.; Turcotte, E.; Carpentier, A.C.; Richard, D. Outdoor temperature, age, sex, body mass index, and diabetic status determine the prevalence, mass, and glucose-uptake activity of 18F-FDG-detected BAT in humans. J. Clin. Endocrinol. Metab. 2011, 96, 192-199. [CrossRef]

47. Blondin, D.P.; Labbé, S.M.; Noll, C.; Kunach, M.; Phoenix, S.; Guérin, B.; Turcotte, É.E.; Haman, F.; Richard, D.; Carpentier, A.C. Selective Impairment of Glucose but Not Fatty Acid or Oxidative Metabolism in Brown Adipose Tissue of Subjects with Type 2 Diabetes. Diabetes 2015, 64, 2388-2397. [CrossRef] [PubMed]

48. Shungin, D.; Winkler, T.W.; Croteau-Chonka, D.C.; Ferreira, T.; Locke, A.E.; Mägi, R.; Strawbridge, R.J.; Pers, T.H.; Fischer, K.; Justice, A.E.; et al. New genetic loci link adipose and insulin biology to body fat distribution. Nature 2015, 518, 187-196. [CrossRef]

49. Wang, Y.; Rimm, E.B.; Stampfer, M.J.; Willett, W.C.; Hu, F.B. Comparison of abdominal adiposity and overall obesity in predicting risk of type 2 diabetes among men. Am. J. Clin. Nutr. 2005, 81, 555-563. [CrossRef]

50. Klein, S.; Allison, D.B.; Heymsfield, S.B.; Kelley, D.E.; Leibel, R.L.; Nonas, C.; Kahn, R. Waist Circumference and Cardiometabolic Risk. A Consensus Statement from Shaping America's Health: Association for Weight Management and Obesity Prevention; NAASO, The Obesity Society; the American Society for Nutrition; and the American Diabetes Association. Diabetes Care 2007, 30, 1647-1652. [CrossRef] [PubMed]

51. Wang, Q.; Zhang, M.; Xu, M.; Gu, W.; Xi, Y.; Qi, L.; Li, B.; Wang, W. Brown adipose tissue activation is inversely related to central obesity and metabolic parameters in adult human. PLOS ONE 2015, 10, e0123795. [CrossRef] 
52. Jespersen, N.Z.; Andersen, M.W.; Jensen, V.H.; Stærkær, T.W.; Severinsen, M.C.K.; Peijs, L.; Soares, R.; Forss, I.; Andersen, E.S.; Hahn, C.H.; et al. Thermogenic genes are blunted whereas brown adipose tissue identity is preserved in human obesity. bioRxiv 2020. [CrossRef]

53. Bartelt, A.; Bruns, O.T.; Reimer, R.; Hohenberg, H.; Ittrich, H.; Peldschus, K.; Kaul, M.G.; Tromsdorf, U.I.; Weller, H.; Waurisch, C.; et al. Brown adipose tissue activity controls triglyceride clearance. Nat. Med. 2011, 17, 200-205. [CrossRef] [PubMed]

54. Berbée, J.F.; Boon, M.R.; Khedoe, P.P.; Bartelt, A.; Schlein, C.; Worthmann, A.; Kooijman, S.; Hoeke, G.; Mol, I.M.; John, C.; et al. Brown fat activation reduces hypercholesterolaemia and protects from atherosclerosis development. Nat. Commun. 2015, 6, 6356. [CrossRef] [PubMed]

55. Raiko, J.; Orava, J.; Savisto, N.; Virtanen, K.A. High Brown Fat Activity Correlates with Cardiovascular Risk Factor Levels Cross-Sectionally and Subclinical Atherosclerosis at 5-Year Follow-Up. Arterioscler. Thromb. Vasc. Biol. 2020, 40, 1289-1295. [CrossRef] [PubMed]

56. Loeliger, R.C.; Maushart, C.I.; Gashi, G.; Senn, J.R.; Felder, M.; Becker, A.S.; Müller, J.; Balaz, M.; Wolfrum, C.; Burger, I.A.; et al. Relation of diet-induced thermogenesis to brown adipose tissue activity in healthy men. Am. J. Physiol. Endocrinol. Metab. 2021, 320, E93-E101. [CrossRef] [PubMed]

57. Deshmukh, A.S.; Peijs, L.; Beaudry, J.L.; Jespersen, N.Z.; Nielsen, C.H.; Ma, T.; Brunner, A.D.; Larsen, T.J.; Bayarri-Olmos, R.; Prabhakar, B.S.; et al. Proteomics-Based Comparative Mapping of the Secretomes of Human Brown and White Adipocytes Reveals EPDR1 as a Novel Batokine. Cell Metab. 2019, 30, 963-975.e7. [CrossRef] [PubMed]

58. Hardman, M.J.; Hull, D. The action of insulin on brown adipose tissue in vivo. J. Physiol. 1972, 221, 85-92. [CrossRef]

59. Orava, J.; Nuutila, P.; Lidell, M.E.; Oikonen, V.; Noponen, T.; Viljanen, T.; Scheinin, M.; Taittonen, M.; Niemi, T.; Enerbäck, S.; et al. Different metabolic responses of human brown adipose tissue to activation by cold and insulin. Cell Metab. 2011, 14, 272-279. [CrossRef]

60. Orava, J.; Nuutila, P.; Noponen, T.; Parkkola, R.; Viljanen, T.; Enerbäck, S.; Rissanen, A.; Pietiläinen, K.H.; Virtanen, K.A. Blunted metabolic responses to cold and insulin stimulation in brown adipose tissue of obese humans. Obesity 2013, 21, $2279-2287$. [CrossRef]

61. Hanssen, M.J.; Hoeks, J.; Brans, B.; van der Lans, A.A.; Schaart, G.; van den Driessche, J.J.; Jörgensen, J.A.; Boekschoten, M.V.; Hesselink, M.K.; Havekes, B.; et al. Short-term cold acclimation improves insulin sensitivity in patients with type 2 diabetes mellitus. Nat. Med. 2015, 21, 863-865. [CrossRef]

62. Hanssen, M.J.; van der Lans, A.A.; Brans, B.; Hoeks, J.; Jardon, K.M.; Schaart, G.; Mottaghy, F.M.; Schrauwen, P.; van Marken Lichtenbelt, W.D. Short-term Cold Acclimation Recruits Brown Adipose Tissue in Obese Humans. Diabetes 2016, 65, 1179-1189. [CrossRef]

63. Okosun, I.S.; Liao, Y.; Rotimi, C.N.; Prewitt, T.E.; Cooper, R.S. Abdominal adiposity and clustering of multiple metabolic syndrome in White, Black and Hispanic Americans. Ann. Epidemiol. 2000, 10, 263-270. [CrossRef]

64. Liu, A.; Byrne, N.M.; Kagawa, M.; Ma, G.; Kijboonchoo, K.; Nasreddine, L.; Koon Poh, B.; Ismail, M.N.; Hills, A.P. Ethnic differences in body fat distribution among Asian pre-pubertal children: A cross-sectional multicenter study. BMC Public Health 2011, 11, 500. [CrossRef]

65. Heymsfield, S.B.; Peterson, C.M.; Thomas, D.M.; Heo, M.; Schuna, J.M., Jr. Why are there race/ethnic differences in adult body mass index-adiposity relationships? A quantitative critical review. Obes. Rev. Off. J. Int. Assoc. Study Obes. 2016, 17, 262-275. [CrossRef]

66. Flegal, K.M.; Carroll, M.D.; Kit, B.K.; Ogden, C.L. Prevalence of Obesity and Trends in the Distribution of Body Mass Index among US Adults, 1999-2010. JAMA 2012, 307, 491-497. [CrossRef]

67. Pham, T.M.; Carpenter, J.R.; Morris, T.P.; Sharma, M.; Petersen, I. Ethnic Differences in the Prevalence of Type 2 Diabetes Diagnoses in the UK: Cross-Sectional Analysis of the Health Improvement Network Primary Care Database. Clin. Epidemiol. 2019, 11, 1081-1088. [CrossRef]

68. Bakker, L.E.H.; Boon, M.R.; van der Linden, R.A.D.; Arias-Bouda, L.P.; van Klinken, J.B.; Smit, F.; Verberne, H.J.; Jukema, J.W.; Tamsma, J.T.; Havekes, L.M.; et al. Brown adipose tissue volume in healthy lean south Asian adults compared with white Caucasians: A prospective, case-controlled observational study. Lancet Diabetes Endocrinol. 2014, 2, 210-217. [CrossRef]

69. Nishimura, T.; Katsumura, T.; Motoi, M.; Oota, H.; Watanuki, S. Experimental evidence reveals the UCP1 genotype changes the oxygen consumption attributed to non-shivering thermogenesis in humans. Sci. Rep. 2017, 7, 5570. [CrossRef]

70. Vijgen, G.H.E.J.; Bouvy, N.D.; Teule, G.J.J.; Brans, B.; Hoeks, J.; Schrauwen, P.; van Marken Lichtenbelt, W.D. Increase in Brown Adipose Tissue Activity after Weight Loss in Morbidly Obese Subjects. J. Clin. Endocrinol. Metab. 2012, 97, E1229-E1233. [CrossRef]

71. Bales, C.W.; Kraus, W.E. Caloric restriction: Implications for human cardiometabolic health. J. Cardiopulm. Rehabil. Prev. 2013, 33, 201-208. [CrossRef]

72. Taylor, R. Calorie restriction for long-term remission of type 2 diabetes. Clin. Med. 2019, 19, 37-42. [CrossRef] [PubMed]

73. Lean, M.E.; Leslie, W.S.; Barnes, A.C.; Brosnahan, N.; Thom, G.; McCombie, L.; Peters, C.; Zhyzhneuskaya, S.; Al-Mrabeh, A.; Hollingsworth, K.G.; et al. Primary care-led weight management for remission of type 2 diabetes (DiRECT): An open-label, cluster-randomised trial. Lancet 2018, 391, 541-551. [CrossRef] 
74. Yang, L.; Licastro, D.; Cava, E.; Veronese, N.; Spelta, F.; Rizza, W.; Bertozzi, B.; Villareal, D.T.; Hotamisligil, G.S.; Holloszy, J.O.; et al. Long-Term Calorie Restriction Enhances Cellular Quality-Control Processes in Human Skeletal Muscle. Cell Rep. 2016, 14, 422-428. [CrossRef]

75. Rikke, B.A.; Yerg, J.E., 3rd; Battaglia, M.E.; Nagy, T.R.; Allison, D.B.; Johnson, T.E. Strain variation in the response of body temperature to dietary restriction. Mech. Ageing Dev. 2003, 124, 663-678. [CrossRef]

76. Mitchell, S.E.; Tang, Z.; Kerbois, C.; Delville, C.; Konstantopedos, P.; Bruel, A.; Derous, D.; Green, C.; Aspden, R.M.; Goodyear, S.R.; et al. The effects of graded levels of calorie restriction: I. impact of short term calorie and protein restriction on body composition in the C57BL/6 mouse. Oncotarget 2015, 6, 15902-15930. [CrossRef] [PubMed]

77. Mitchell, S.E.; Tang, Z.; Kerbois, C.; Delville, C.; Derous, D.; Green, C.L.; Wang, Y.; Han, J.J.D.; Chen, L.; Douglas, A.; et al. The effects of graded levels of calorie restriction: VIII. Impact of short term calorie and protein restriction on basal metabolic rate in the C57BL/ 6 mouse. Oncotarget 2017, 8, 17453-17474. [CrossRef]

78. Selman, C.; Phillips, T.; Staib, J.L.; Duncan, J.S.; Leeuwenburgh, C.; Speakman, J.R. Energy expenditure of calorically restricted rats is higher than predicted from their altered body composition. Mech. Ageing Dev. 2005, 126, 783-793. [CrossRef]

79. Fabbiano, S.; Suárez-Zamorano, N.; Rigo, D.; Veyrat-Durebex, C.; Stevanovic Dokic, A.; Colin, D.J.; Trajkovski, M. Caloric Restriction Leads to Browning of White Adipose Tissue through Type 2 Immune Signaling. Cell Metab. 2016, 24, 434-446. [CrossRef] [PubMed]

80. Barquissau, V.; Léger, B.; Beuzelin, D.; Martins, F.; Amri, E.Z.; Pisani, D.F.; Saris, W.H.M.; Astrup, A.; Maoret, J.J.; Iacovoni, J.; et al. Caloric Restriction and Diet-Induced Weight Loss Do Not Induce Browning of Human Subcutaneous White Adipose Tissue in Women and Men with Obesity. Cell Rep. 2018, 22, 1079-1089. [CrossRef]

81. Bredella, M.A.; Fazeli, P.K.; Freedman, L.M.; Calder, G.; Lee, H.; Rosen, C.J.; Klibanski, A. Young women with cold-activated brown adipose tissue have higher bone mineral density and lower Pref- 1 than women without brown adipose tissue: A study in women with anorexia nervosa, women recovered from anorexia nervosa, and normal-weight women. J. Clin. Endocrinol. Metab. 2012, 97, E584-E590. [CrossRef]

82. Fagher, B.; Monti, M.; Theander, S. Microcalorimetric study of muscle and platelet thermogenesis in anorexia nervosa and bulimia. Am. J. Clin. Nutr. 1989, 49, 476-481. [CrossRef] [PubMed]

83. Steinberg, J.D.; Vogel, W.; Vegt, E. Factors influencing brown fat activation in FDG PET/CT: A retrospective analysis of 15,000+ cases. Br. J. Radiol. 2017, 90, 20170093. [CrossRef] [PubMed]

84. Pasanisi, F.; Pace, L.; Fonti, R.; Marra, M.; Sgambati, D.; De Caprio, C.; De Filippo, E.; Vaccaro, A.; Salvatore, M.; Contaldo, F. Evidence of Brown Fat Activity in Constitutional Leanness. J. Clin. Endocrinol. Metab. 2013, 98, 1214-1218. [CrossRef] [PubMed]

85. Garg, A. Lipodystrophies: Genetic and acquired body fat disorders. J. Clin. Endocrinol. Metab. 2011, 96, 3313-3325. [CrossRef]

86. Magré, J.; Delépine, M.; Khallouf, E.; Gedde-Dahl, T.; Van Maldergem, L.; Sobel, E.; Papp, J.; Meier, M.; Mégarbané, A.; BSCL Working Group; et al. Identification of the gene altered in Berardinelli-Seip congenital lipodystrophy on chromosome 11q13. Nat. Genet. 2001, 28, 365-370. [CrossRef] [PubMed]

87. Chen, W.; Yechoor, V.K.; Chang, B.H.-J.; Li, M.V.; March, K.L.; Chan, L. The Human Lipodystrophy Gene Product Berardinelli-Seip Congenital Lipodystrophy 2/Seipin Plays a Key Role in Adipocyte Differentiation. Endocrinology 2009, 150, 4552-4561. [CrossRef]

88. Zhou, H.; Xu, C.; Lee, H.; Yoon, Y.; Chen, W. Berardinelli-Seip congenital lipodystrophy 2/SEIPIN determines brown adipose tissue maintenance and thermogenic programing. Mol. Metab. 2020, 36, 100971. [CrossRef]

89. Pellegrini, C.; Columbaro, M.; Schena, E.; Prencipe, S.; Andrenacci, D.; Iozzo, P.; Angela Guzzardi, M.; Capanni, C.; Mattioli, E.; Loi, M.; et al. Altered adipocyte differentiation and unbalanced autophagy in type 2 Familial Partial Lipodystrophy: An in vitro and in vivo study of adipose tissue browning. Exp. Mol. Med. 2019, 51, 1-17. [CrossRef]

90. Yoneshiro, T.; Matsushita, M.; Saito, M. Translational Aspects of Brown Fat Activation by Food-Derived Stimulants. Handb. Exp. Pharmacol. 2019, 251, 359-379. [CrossRef]

91. Van Marken Lichtenbelt, W.D.; Schrauwen, P. Implications of nonshivering thermogenesis for energy balance regulation in humans. Am. J. Physiol. Regul. Integr. Comp. Physiol. 2011, 301, R285-R296. [CrossRef]

92. Glick, Z.; Teague, R.J.; Bray, G.A. Brown adipose tissue: Thermic response increased by a single low protein, high carbohydrate meal. Science 1981, 213, 1125-1127. [CrossRef]

93. Ma, S.W.; Foster, D.O.; Nadeau, B.E.; Triandafillou, J. Absence of increased oxygen consumption in brown adipose tissue of rats exhibiting "cafeteria" diet-induced thermogenesis. Can. J. Physiol. Pharmacol. 1988, 66, 1347-1354. [CrossRef]

94. Betz, M.J.; Bielohuby, M.; Mauracher, B.; Abplanalp, W.; Müller, H.-H.; Pieper, K.; Ramisch, J.; Tschöp, M.H.; Beuschlein, F.; Bidlingmaier, M.; et al. Isoenergetic Feeding of Low Carbohydrate-High Fat Diets Does Not Increase Brown Adipose Tissue Thermogenic Capacity in Rats. PLoS ONE 2012, 7, e38997. [CrossRef]

95. Westerterp, K.R. Diet induced thermogenesis. Nutr. Metab. 2004, 1, 5. [CrossRef]

96. Din, M.U.; Saari, T.; Raiko, J.; Kudomi, N.; Maurer, S.F.; Lahesmaa, M.; Fromme, T.; Amri, E.-Z.; Klingenspor, M.; Solin, O.; et al. Postprandial Oxidative Metabolism of Human Brown Fat Indicates Thermogenesis. Cell Metab. 2018, 28, 207-216.e3. [CrossRef]

97. Hibi, M.; Oishi, S.; Matsushita, M.; Yoneshiro, T.; Yamaguchi, T.; Usui, C.; Yasunaga, K.; Katsuragi, Y.; Kubota, K.; Tanaka, S.; et al. Brown adipose tissue is involved in diet-induced thermogenesis and whole-body fat utilization in healthy humans. Int. J. Obes. 2016, 40, 1655-1661. [CrossRef]

98. Maffeis, C.; Schutz, Y.; Grezzani, A.; Provera, S.; Piacentini, G.; Tatò, L. Meal-Induced Thermogenesis and Obesity: Is a Fat Meal a Risk Factor for Fat Gain in Children? J. Clin. Endocrinol. Metab. 2001, 86, 214-219. [CrossRef] 
99. Conceição, E.P.S.; Reynolds, C.A.; Morrison, S.F.; Madden, C.J. Activation of Transient Receptor Potential Vanilloid 1 Channels in the Nucleus of the Solitary Tract and Activation of Dynorphin Input to the Median Preoptic Nucleus Contribute to Impaired BAT Thermogenesis in Diet-Induced Obesity. eNeuro 2021, 8. [CrossRef]

100. Ohtomo, T.; Ino, K.; Miyashita, R.; Chigira, M.; Nakamura, M.; Someya, K.; Inaba, N.; Fujita, M.; Takagi, M.; Yamada, J. Chronic high-fat feeding impairs adaptive induction of mitochondrial fatty acid combustion-associated proteins in brown adipose tissue of mice. Biochem. Biophys. Rep. 2017, 10, 32-38. [CrossRef]

101. De França, S.A.; dos Santos, M.P.; Przygodda, F.; Garófalo, M.A.; Kettelhut, I.C.; Magalhães, D.A.; Bezerra, K.S.; Colodel, E.M.; Flouris, A.D.; Andrade, C.M.; et al. A Low-Protein, High-Carbohydrate Diet Stimulates Thermogenesis in the Brown Adipose Tissue of Rats via ATF-2. Lipids 2016, 51, 303-310. [CrossRef]

102. Vosselman, M.J.; Brans, B.; van der Lans, A.A.; Wierts, R.; van Baak, M.A.; Mottaghy, F.M.; Schrauwen, P.; van Marken Lichtenbelt, W.D. Brown adipose tissue activity after a high-calorie meal in humans. Am. J. Clin. Nutr. 2013, 98, 57-64. [CrossRef] [PubMed]

103. Rahmouni, K.; Morgan, D.A.; Morgan, G.M.; Liu, X.; Sigmund, C.D.; Mark, A.L.; Haynes, W.G. Hypothalamic PI3K and MAPK differentially mediate regional sympathetic activation to insulin. J. Clin. Investig. 2004, 114, 652-658. [CrossRef]

104. Sakaguchi, T.; Takahashi, M.; Bray, G.A. Diurnal changes in sympathetic activity. Relation to food intake and to insulin injected into the ventromedial or suprachiasmatic nucleus. J. Clin. Investig. 1988, 82, 282-286. [CrossRef]

105. Fromme, T.; Klingenspor, M. Uncoupling protein 1 expression and high-fat diets. Am. J. Physiol. Regul. Integr. Comp. Physiol. 2011, 300, R1-R8. [CrossRef] [PubMed]

106. Vögler, O.; López-Bellan, A.; Alemany, R.; Tofé, S.; González, M.; Quevedo, J.; Pereg, V.; Barceló, F.; Escriba, P.V. Structure-effect relation of C18 long-chain fatty acids in the reduction of body weight in rats. Int. J. Obes. 2008, 32, 464-473. [CrossRef]

107. Sayegh, A.I. The role of cholecystokinin receptors in the short-term control of food intake. Prog. Mol. Biol. Transl. Sci. 2013, 114, 277-316. [CrossRef]

108. Wang, R.; Lu, Y.; Cicha, M.Z.; Singh, M.V.; Benson, C.J.; Madden, C.J.; Chapleau, M.W.; Abboud, F.M. TMEM16B determines cholecystokinin sensitivity of intestinal vagal afferents of nodose neurons. JCI Insight 2019, 4. [CrossRef]

109. Yamazaki, T.; Morimoto-Kobayashi, Y.; Koizumi, K.; Takahashi, C.; Nakajima, S.; Kitao, S.; Taniguchi, Y.; Katayama, M.; Ogawa, Y. Secretion of a gastrointestinal hormone, cholecystokinin, by hop-derived bitter components activates sympathetic nerves in brown adipose tissue. J. Nutr. Biochem. 2019, 64, 80-87. [CrossRef]

110. Blouet, C.; Schwartz, G.J. Duodenal Lipid Sensing Activates Vagal Afferents to Regulate Non-Shivering Brown Fat Thermogenesis in Rats. PLoS ONE 2012, 7, e51898. [CrossRef]

111. Fleckenstein-Elsen, M.; Dinnies, D.; Jelenik, T.; Roden, M.; Romacho, T.; Eckel, J. Eicosapentaenoic acid and arachidonic acid differentially regulate adipogenesis, acquisition of a brite phenotype and mitochondrial function in primary human adipocytes. Mol. Nutr. Food Res. 2016, 60, 2065-2075. [CrossRef]

112. Blondin, D.P.; Tingelstad, H.C.; Noll, C.; Frisch, F.; Phoenix, S.; Guérin, B.; Turcotte, É.E.; Richard, D.; Haman, F.; Carpentier, A.C. Dietary fatty acid metabolism of brown adipose tissue in cold-acclimated men. Nat. Commun. 2017, 8, 14146. [CrossRef]

113. Glick, Z.; Raum, W.J. Norepinephrine turnover in brown adipose tissue is stimulated by a single meal. Am. J. Physiol. Regul. Integr. Comp. Physiol. 1986, 251, R13-R17. [CrossRef]

114. Brito, M.N.; Brito, N.A.; Migliorini, R.H. Thermogenic capacity of brown adipose tissue is reduced in rats fed a high protein, carbohydrate-free diet. J. Nutr. 1992, 122, 2081-2086. [CrossRef] [PubMed]

115. Huang, X.; Hancock, D.P.; Gosby, A.K.; McMahon, A.C.; Solon, S.M.C.; Le Couteur, D.G.; Conigrave, A.D.; Raubenheimer, D.; Simpson, S.J. Effects of dietary protein to carbohydrate balance on energy intake, fat storage, and heat production in mice. Obesity 2013, 21, 85-92. [CrossRef]

116. Klaus, S. Increasing the protein: Carbohydrate ratio in a high-fat diet delays the development of adiposity and improves glucose homeostasis in mice. J. Nutr. 2005, 135, 1854-1858. [CrossRef] [PubMed]

117. Petzke, K.J.; Friedrich, M.; Metges, C.C.; Klaus, S. Long-term dietary high protein intake up-regulates tissue specific gene expression of uncoupling proteins 1 and 2 in rats. Eur. J. Nutr. 2005, 44, 414-421. [CrossRef]

118. Young, J.B.; Kaufman, L.N.; Saville, M.E.; Landsberg, L. Increased sympathetic nervous system activity in rats fed a low-protein diet. Am. J. Physiol. Regul. Integr. Comp. Physiol. 1985, 248, R627-R637. [CrossRef]

119. Liisberg, U.; Myrmel, L.S.; Fjære, E.; Rønnevik, A.K.; Bjelland, S.; Fauske, K.R.; Holm, J.B.; Basse, A.L.; Hansen, J.B.; Liaset, B.; et al. The protein source determines the potential of high protein diets to attenuate obesity development in C57BL/6J mice. Adipocyte 2016, 5, 196-211. [CrossRef] [PubMed]

120. Weigle, D.S.; Breen, P.A.; Matthys, C.C.; Callahan, H.S.; Meeuws, K.E.; Burden, V.R.; Purnell, J.Q. A high-protein diet induces sustained reductions in appetite, ad libitum caloric intake, and body weight despite compensatory changes in diurnal plasma leptin and ghrelin concentrations. Am. J. Clin. Nutr. 2005, 82, 41-48. [CrossRef]

121. Westerterp-Plantenga, M.S.; Rolland, V.; Wilson, S.A.; Westerterp, K.R. Satiety related to $24 \mathrm{~h}$ diet-induced thermogenesis during high protein/carbohydrate vs high fat diets measured in a respiration chamber. Eur. J. Clin. Nutr. 1999, 53, 495-502. [CrossRef]

122. Veldhorst, M.; Smeets, A.; Soenen, S.; Hochstenbach-Waelen, A.; Hursel, R.; Diepvens, K.; Lejeune, M.; Luscombe-Marsh, N.; Westerterp-Plantenga, M. Protein-induced satiety: Effects and mechanisms of different proteins. Physiol. Behav. 2008, 94, 300-307. [CrossRef]

123. Caterina, M.J.; Schumacher, M.A.; Tominaga, M.; Rosen, T.A.; Levine, J.D.; Julius, D. The capsaicin receptor: A heat-activated ion channel in the pain pathway. Nature 1997, 389, 816-824. [CrossRef] [PubMed] 
124. Szallasi, A.; Blumberg, P.M. Vanilloid (Capsaicin) receptors and mechanisms. Pharmacol. Rev. 1999, 51, 159-212. [PubMed]

125. Gavva, N.R.; Bannon, A.W.; Surapaneni, S.; Hovland, D.N.; Lehto, S.G.; Gore, A.; Juan, T.; Deng, H.; Han, B.; Klionsky, L.; et al. The Vanilloid Receptor TRPV1 Is Tonically Activated In Vivo and Involved in Body Temperature Regulation. J. Neurosci. 2007, 27, 3366-3374. [CrossRef] [PubMed]

126. Ono, K.; Tsukamoto-Yasui, M.; Hara-Kimura, Y.; Inoue, N.; Nogusa, Y.; Okabe, Y.; Nagashima, K.; Kato, F. Intragastric administration of capsiate, a transient receptor potential channel agonist, triggers thermogenic sympathetic responses. J. Appl. Physiol. 2011, 110, 789-798. [CrossRef] [PubMed]

127. Steiner, A.A.; Turek, V.F.; Almeida, M.C.; Burmeister, J.J.; Oliveira, D.L.; Roberts, J.L.; Bannon, A.W.; Norman, M.H.; Louis, J.-C.; Treanor, J.J.S.; et al. Nonthermal Activation of Transient Receptor Potential Vanilloid-1 Channels in Abdominal Viscera Tonically Inhibits Autonomic Cold-Defense Effectors. J. Neurosci. 2007, 27, 7459-7468. [CrossRef] [PubMed]

128. Mohammed, M.; Madden, C.J.; Andresen, M.C.; Morrison, S.F. Activation of TRPV1 in nucleus tractus solitarius reduces brown adipose tissue thermogenesis, arterial pressure, and heart rate. Am. J. Physiol. Regul. Integr. Comp. Physiol. 2018, 315, R134-R143. [CrossRef] [PubMed]

129. Baskaran, P.; Krishnan, V.; Ren, J.; Thyagarajan, B. Capsaicin induces browning of white adipose tissue and counters obesity by activating TRPV1 channel-dependent mechanisms. Br. J. Pharmacol. 2016, 173, 2369-2389. [CrossRef]

130. Kawabata, F.; Inoue, N.; Masamoto, Y.; Matsumura, S.; Kimura, W.; Kadowaki, M.; Higashi, T.; Tominaga, M.; Inoue, K.; Fushiki, T. Non-pungent capsaicin analogs (capsinoids) increase metabolic rate and enhance thermogenesis via gastrointestinal TRPV1 in mice. Biosci. Biotechnol. Biochem. 2009, 73, 2690-2697. [CrossRef]

131. Yoneshiro, T.; Aita, S.; Kawai, Y.; Iwanaga, T.; Saito, M. Nonpungent capsaicin analogs (capsinoids) increase energy expenditure through the activation of brown adipose tissue in humans. Am. J. Clin. Nutr. 2012, 95, 845-850. [CrossRef]

132. Sun, L.; Camps, S.G.; Goh, H.J.; Govindharajulu, P.; Schaefferkoetter, J.D.; Townsend, D.W.; Verma, S.K.; Velan, S.S.; Sun, L.; Sze, S.K.; et al. Capsinoids activate brown adipose tissue (BAT) with increased energy expenditure associated with subthreshold 18-fluorine fluorodeoxyglucose uptake in BAT-positive humans confirmed by positron emission tomography scan. Am. J. Clin. Nutr. 2018, 107, 62-70. [CrossRef]

133. Yoneshiro, T.; Aita, S.; Matsushita, M.; Kayahara, T.; Kameya, T.; Kawai, Y.; Iwanaga, T.; Saito, M. Recruited brown adipose tissue as an antiobesity agent in humans. J. Clin. Investig. 2013, 123, 3404-3408. [CrossRef]

134. Qie, X.; Wu, Y.; Chen, Y.; Liu, C.; Zeng, M.; Qin, F.; Wang, Z.; Chen, J.; He, Z. Competitive interactions among tea catechins, proteins, and digestive enzymes modulate in vitro protein digestibility, catechin bioaccessibility, and antioxidant activity of milk tea beverage model systems. Food Res. Int. 2021, 140, 110050. [CrossRef] [PubMed]

135. Hursel, R.; Viechtbauer, W.; Dulloo, A.G.; Tremblay, A.; Tappy, L.; Rumpler, W.; Westerterp-Plantenga, M.S. The effects of catechin rich teas and caffeine on energy expenditure and fat oxidation: A meta-analysis. Obes. Rev. 2011, 12, e573-e581. [CrossRef] [PubMed]

136. Yoneshiro, T.; Matsushita, M.; Hibi, M.; Tone, H.; Takeshita, M.; Yasunaga, K.; Katsuragi, Y.; Kameya, T.; Sugie, H.; Saito, M. Tea catechin and caffeine activate brown adipose tissue and increase cold-induced thermogenic capacity in humans. Am. J. Clin. Nutr. 2017, 105, 873-881. [CrossRef]

137. Nirengi, S.; Yoneshiro, T.; Sugie, H.; Saito, M.; Hamaoka, T. Human brown adipose tissue assessed by simple, noninvasive near-infrared time-resolved spectroscopy. Obesity 2015, 23, 973-980. [CrossRef]

138. Nirengi, S.; Amagasa, S.; Homma, T.; Yoneshiro, T.; Matsumiya, S.; Kurosawa, Y.; Sakane, N.; Ebi, K.; Saito, M.; Hamaoka, T. Daily ingestion of catechin-rich beverage increases brown adipose tissue density and decreases extramyocellular lipids in healthy young women. SpringerPlus 2016, 5, 1363. [CrossRef]

139. Venkatachalam, K.; Montell, C. TRP channels. Annu. Rev. Biochem. 2007, 76, 387-417. [CrossRef]

140. Bautista, D.M.; Siemens, J.; Glazer, J.M.; Tsuruda, P.R.; Basbaum, A.I.; Stucky, C.L.; Jordt, S.-E.; Julius, D. The menthol receptor TRPM8 is the principal detector of environmental cold. Nature 2007, 448, 204-208. [CrossRef]

141. Typolt, O.; Filingeri, D. Evidence for the involvement of peripheral cold-sensitive TRPM8 channels in human cutaneous hygrosensation. Am. J. Physiol. Regul. Integr. Comp. Physiol. 2020, 318, R579-R589. [CrossRef]

142. Ma, S.; Yu, H.; Zhao, Z.; Luo, Z.; Chen, J.; Ni, Y.; Jin, R.; Ma, L.; Wang, P.; Zhu, Z.; et al. Activation of the cold-sensing TRPM8 channel triggers UCP1-dependent thermogenesis and prevents obesity. J. Mol. Cell Biol. 2012, 4, 88-96. [CrossRef] [PubMed]

143. Rossato, M.; Granzotto, M.; Macchi, V.; Porzionato, A.; Petrelli, L.; Calcagno, A.; Vencato, J.; De Stefani, D.; Silvestrin, V.; Rizzuto, R.; et al. Human white adipocytes express the cold receptor TRPM8 which activation induces UCP1 expression, mitochondrial activation and heat production. Mol. Cell. Endocrinol. 2014, 383, 137-146. [CrossRef]

144. Valente, A.; Carrillo, A.E.; Tzatzarakis, M.N.; Vakonaki, E.; Tsatsakis, A.M.; Kenny, G.P.; Koutedakis, Y.; Jamurtas, A.Z.; Flouris, A.D. The absorption and metabolism of a single L-menthol oral versus skin administration: Effects on thermogenesis and metabolic rate. Food Chem. Toxicol. 2015, 86, 262-273. [CrossRef]

145. González-Muñiz, R.; Bonache, M.A.; Martín-Escura, C.; Gómez-Monterrey, I. Recent Progress in TRPM8 Modulation: An Update. Int. J. Mol. Sci. 2019, 20, 2618. [CrossRef]

146. Shen, W.; Chuang, C.C.; Martinez, K.; Reid, T.; Brown, J.M.; Xi, L.; Hixson, L.; Hopkins, R.; Starnes, J.; McIntosh, M. Conjugated linoleic acid reduces adiposity and increases markers of browning and inflammation in white adipose tissue of mice. J. Lipid Res. 2013, 54, 909-922. [CrossRef] 
147. Wang, S.; Wang, X.; Ye, Z.; Xu, C.; Zhang, M.; Ruan, B.; Wei, M.; Jiang, Y.; Zhang, Y.; Wang, L.; et al. Curcumin promotes browning of white adipose tissue in a norepinephrine-dependent way. Biochem. Biophys. Res. Commun. 2015, 466, 247-253. [CrossRef] [PubMed]

148. Lone, J.; Choi, J.H.; Kim, S.W.; Yun, J.W. Curcumin induces brown fat-like phenotype in 3T3-L1 and primary white adipocytes. J. Nutr. Biochem. 2016, 27, 193-202. [CrossRef] [PubMed]

149. Oi, Y.; Kawada, T.; Shishido, C.; Wada, K.; Kominato, Y.; Nishimura, S.; Ariga, T.; Iwai, K. Allyl-containing sulfides in garlic increase uncoupling protein content in brown adipose tissue, and noradrenaline and adrenaline secretion in rats. J. Nutr. 1999, 129, 336-342. [CrossRef]

150. Kanamoto, Y.; Yamashita, Y.; Nanba, F.; Yoshida, T.; Tsuda, T.; Fukuda, I.; Nakamura-Tsuruta, S.; Ashida, H. A Black Soybean Seed Coat Extract Prevents Obesity and Glucose Intolerance by Up-regulating Uncoupling Proteins and Down-regulating Inflammatory Cytokines in High-Fat Diet-Fed Mice. J. Agric. Food Chem. 2011, 59, 8985-8993. [CrossRef]

151. Andrade, J.M.O.; Frade, A.C.M.; Guimarães, J.B.; Freitas, K.M.; Lopes, M.T.P.; Guimarães, A.L.S.; de Paula, A.M.B.; Coimbra, C.C.; Santos, S.H.S. Resveratrol increases brown adipose tissue thermogenesis markers by increasing SIRT1 and energy expenditure and decreasing fat accumulation in adipose tissue of mice fed a standard diet. Eur. J. Nutr. 2014, 53, 1503-1510. [CrossRef]

152. Sugita, J.; Yoneshiro, T.; Hatano, T.; Aita, S.; Ikemoto, T.; Uchiwa, H.; Iwanaga, T.; Kameya, T.; Kawai, Y.; Saito, M. Grains of paradise (Aframomum melegueta) extract activates brown adipose tissue and increases whole-body energy expenditure in men. $\mathrm{Br}$. J. Nutr. 2013, 110, 733-738. [CrossRef] [PubMed]

153. Matsushita, M.; Yoneshiro, T.; Aita, S.; Kamiya, T.; Kusaba, N.; Yamaguchi, K.; Takagaki, K.; Kameya, T.; Sugie, H.; Saito, M. Kaempferia parviflora extract increases whole-body energy expenditure in humans: Roles of brown adipose tissue. J. Nutr. Sci. Vitaminol. 2015, 61, 79-83. [CrossRef] [PubMed]

154. Palmeri, R.; Monteleone, J.I.; Spagna, G.; Restuccia, C.; Raffaele, M.; Vanella, L.; Li Volti, G.; Barbagallo, I. Olive Leaf Extract from Sicilian Cultivar Reduced Lipid Accumulation by Inducing Thermogenic Pathway during Adipogenesis. Front. Pharmacol. 2016, 7, 143. [CrossRef] [PubMed]

155. Kim, K.M.; Kim, S.M.; Cho, D.Y.; Park, S.J.; Joo, N.S. The Effect of Xanthigen on the Expression of Brown Adipose Tissue Assessed by ${ }^{18}$ F-FDG PET. Yonsei Med. J. 2016, 57, 1038-1041. [CrossRef]

156. Bonet, M.L.; Mercader, J.; Palou, A. A nutritional perspective on UCP1-dependent thermogenesis. Biochimie 2017, 134, 99-117. [CrossRef] [PubMed]

157. Michlig, S.; Merlini, J.M.; Beaumont, M.; Ledda, M.; Tavenard, A.; Mukherjee, R.; Camacho, S.; le Coutre, J. Effects of TRP channel agonist ingestion on metabolism and autonomic nervous system in a randomized clinical trial of healthy subjects. Sci. Rep. 2016, 6, 20795. [CrossRef] [PubMed]

158. Jiang, J.; Emont, M.P.; Jun, H.; Qiao, X.; Liao, J.; Kim, D.-I.; Wu, J. Cinnamaldehyde induces fat cell-autonomous thermogenesis and metabolic reprogramming. Metabolism 2017, 77, 58-64. [CrossRef]

159. Carey, A.L.; Formosa, M.F.; Van Every, B.; Bertovic, D.; Eikelis, N.; Lambert, G.W.; Kalff, V.; Duffy, S.J.; Cherk, M.H.; Kingwell, B.A. Ephedrine activates brown adipose tissue in lean but not obese humans. Diabetologia 2013, 56, 147-155. [CrossRef]

160. Johnstone, A.M. Safety and efficacy of high-protein diets for weight loss. Proc. Nutr. Soc. 2012, 71, 339-349. [CrossRef]

161. Zhao, W.-T.; Luo, Y.; Zhang, Y.; Zhou, Y.; Zhao, T.-T. High protein diet is of benefit for patients with type 2 diabetes: An updated meta-analysis. Medicine 2018, 97, e13149. [CrossRef]

162. Dong, J.Y.; Zhang, Z.L.; Wang, P.Y.; Qin, L.Q. Effects of high-protein diets on body weight, glycaemic control, blood lipids and blood pressure in type 2 diabetes: Meta-analysis of randomised controlled trials. Br. J. Nutr. 2013, 110, 781-789. [CrossRef] [PubMed]

163. Choi, Y.J.; Jeon, S.-M.; Shin, S. Impact of a Ketogenic Diet on Metabolic Parameters in Patients with Obesity or Overweight and with or without Type 2 Diabetes: A Meta-Analysis of Randomized Controlled Trials. Nutrients 2020, 12, 2005. [CrossRef] [PubMed]

164. Zheng, J.; Zheng, S.; Feng, Q.; Zhang, Q.; Xiao, X. Dietary capsaicin and its anti-obesity potency: From mechanism to clinical implications. Biosci. Rep. 2017, 37. [CrossRef] [PubMed]

165. Chang, A.; Rosani, A.; Quick, J. Capsaicin; StatPearls Publishing: Treasure Island, FL, USA, 2021.

166. Ohyama, K.; Nogusa, Y.; Suzuki, K.; Shinoda, K.; Kajimura, S.; Bannai, M. A combination of exercise and capsinoid supplementation additively suppresses diet-induced obesity by increasing energy expenditure in mice. Am. J. Physiol. Endocrinol. Metab. 2015, 308, E315-E323. [CrossRef]

167. Bernard, B.K.; Tsubuku, S.; Kayahara, T.; Maeda, K.; Hamada, M.; Nakamura, T.; Shirai, Y.; Nakayama, A.; Ueno, S.; Mihara, R. Studies of the toxicological potential of capsinoids: X. Safety assessment and pharmacokinetics of capsinoids in healthy male volunteers after a single oral ingestion of CH-19 Sweet extract. Int. J. Toxicol. 2008, 27 (Suppl. 3), 137-147. [CrossRef]

168. Patel, S.S.; Beer, S.; Kearney, D.L.; Phillips, G.; Carter, B.A. Green tea extract: A potential cause of acute liver failure. World J. Gastroenterol. 2013, 19, 5174-5177. [CrossRef] [PubMed]

169. EFSA Panel on Food Additives and Nutrient Sources added to Food (ANS); Younes, M.; Aggett, P.; Aguilar, F.; Crebelli, R.; Dusemund, B.; Filipič, M.; Frutos, M.J.; Galtier, P.; Gott, D.; et al. Scientific opinion on the safety of green tea catechins. EFSA J. 2018, 16, e05239. [CrossRef]

170. Zhu, R.; Liu, H.; Liu, C.; Wang, L.; Ma, R.; Chen, B.; Li, L.; Niu, J.; Fu, M.; Zhang, D.; et al. Cinnamaldehyde in diabetes: A review of pharmacology, pharmacokinetics and safety. Pharmacol. Res. 2017, 122, 78-89. [CrossRef] 
171. Shreaz, S.; Wani, W.A.; Behbehani, J.M.; Raja, V.; Irshad, M.; Karched, M.; Ali, I.; Siddiqi, W.A.; Hun, L.T. Cinnamaldehyde and its derivatives, a novel class of antifungal agents. Fitoterapia 2016, 112, 116-131. [CrossRef]

172. Mereto, E.; Brambilla-Campart, G.; Ghia, M.; Martelli, A.; Brambilla, G. Cinnamaldehyde-induced micronuclei in rodent liver. Mutat. Res. Genet. Toxicol. 1994, 322, 1-8. [CrossRef]

173. Thyfault, J.P.; Bergouignan, A. Exercise and metabolic health: Beyond skeletal muscle. Diabetologia 2020, 63, 1464-1474. [CrossRef]

174. Lee, P.; Greenfield, J.R.; Ho, K.K.; Fulham, M.J. A critical appraisal of the prevalence and metabolic significance of brown adipose tissue in adult humans. Am. J. Physiol. Endocrinol. Metab. 2010, 299, E601-E606. [CrossRef] [PubMed]

175. Yoshioka, K.; Yoshida, T.; Wakabayashi, Y.; Nishioka, H.; Kondo, M. Effects of exercise training on brown adipose tissue thermogenesis in ovariectomized obese rats. Endocrinol. Jpn. 1989, 36, 403-408. [CrossRef] [PubMed]

176. Ignacio, D.L.; Fortunato, R.S.; Neto, R.A.; da Silva Silvestre, D.H.; Nigro, M.; Frankenfeld, T.G.; Werneck-de-Castro, J.P.; Carvalho, D.P. Blunted response of pituitary type 1 and brown adipose tissue type 2 deiodinases to swimming training in ovariectomized rats. Horm. Metab. Res. 2012, 44, 797-803. [CrossRef] [PubMed]

177. Wu, M.V.; Bikopoulos, G.; Hung, S.; Ceddia, R.B. Thermogenic capacity is antagonistically regulated in classical brown and white subcutaneous fat depots by high fat diet and endurance training in rats: Impact on whole-body energy expenditure. J. Biol. Chem. 2014, 289, 34129-34140. [CrossRef]

178. Dewal, R.S.; Stanford, K.I. Effects of exercise on brown and beige adipocytes. Biochim. Biophys. Acta 2019, 1864, 71-78. [CrossRef]

179. Vosselman, M.J.; Hoeks, J.; Brans, B.; Pallubinsky, H.; Nascimento, E.B.; van der Lans, A.A.; Broeders, E.P.; Mottaghy, F.M.; Schrauwen, P.; van Marken Lichtenbelt, W.D. Low brown adipose tissue activity in endurance-trained compared with lean sedentary men. Int. J. Obes. 2015, 39, 1696-1702. [CrossRef]

180. Motiani, P.; Virtanen, K.A.; Motiani, K.K.; Eskelinen, J.J.; Middelbeek, R.J.; Goodyear, L.J.; Savolainen, A.M.; Kemppainen, J.; Jensen, J.; Din, M.U.; et al. Decreased insulin-stimulated brown adipose tissue glucose uptake after short-term exercise training in healthy middle-aged men. Diabetes Obes. Metab. 2017, 19, 1379-1388. [CrossRef]

181. Reichkendler, M.H.; Auerbach, P.; Rosenkilde, M.; Christensen, A.N.; Holm, S.; Petersen, M.B.; Lagerberg, A.; Larsson, H.B.W.; Rostrup, E.; Mosbech, T.H.; et al. Exercise training favors increased insulin-stimulated glucose uptake in skeletal muscle in contrast to adipose tissue: A randomized study using FDG PET imaging. Am. J. Physiol. Endocrinol. Metab. 2013, 305, E496-E506. [CrossRef]

182. Stanford, K.I.; Middelbeek, R.J.; Townsend, K.L.; Lee, M.Y.; Takahashi, H.; So, K.; Hitchcox, K.M.; Markan, K.R.; Hellbach, K.; Hirshman, M.F.; et al. A novel role for subcutaneous adipose tissue in exercise-induced improvements in glucose homeostasis. Diabetes 2015, 64, 2002-2014. [CrossRef] [PubMed]

183. Knudsen, J.G.; Murholm, M.; Carey, A.L.; Biensø, R.S.; Basse, A.L.; Allen, T.L.; Hidalgo, J.; Kingwell, B.A.; Febbraio, M.A.; Hansen, J.B.; et al. Role of IL-6 in exercise training- and cold-induced UCP1 expression in subcutaneous white adipose tissue. PLoS ONE 2014, 9, e84910. [CrossRef] [PubMed]

184. Boström, P.; Wu, J.; Jedrychowski, M.P.; Korde, A.; Ye, L.; Lo, J.C.; Rasbach, K.A.; Boström, E.A.; Choi, J.H.; Long, J.Z.; et al. A PGC1- $\alpha$-dependent myokine that drives brown-fat-like development of white fat and thermogenesis. Nature 2012, 481, 463-468. [CrossRef]

185. Rao, R.R.; Long, J.Z.; White, J.P.; Svensson, K.J.; Lou, J.; Lokurkar, I.; Jedrychowski, M.P.; Ruas, J.L.; Wrann, C.D.; Lo, J.C.; et al. Meteorin-like is a hormone that regulates immune-adipose interactions to increase beige fat thermogenesis. Cell 2014, 157, 1279-1291. [CrossRef] [PubMed]

186. Norheim, F.; Langleite, T.M.; Hjorth, M.; Holen, T.; Kielland, A.; Stadheim, H.K.; Gulseth, H.L.; Birkeland, K.I.; Jensen, J.; Drevon, C.A. The effects of acute and chronic exercise on PGC-1 $\alpha$, irisin and browning of subcutaneous adipose tissue in humans. FEBS J. 2014, 281, 739-749. [CrossRef]

187. Stanford, K.I.; Lynes, M.D.; Takahashi, H.; Baer, L.A.; Arts, P.J.; May, F.J.; Lehnig, A.C.; Middelbeek, R.J.W.; Richard, J.J.; So, K.; et al. 12,13-diHOME: An Exercise-Induced Lipokine that Increases Skeletal Muscle Fatty Acid Uptake. Cell Metab. 2018, 27, 1111-1120.e3. [CrossRef]

188. Zingaretti, M.C.; Crosta, F.; Vitali, A.; Guerrieri, M.; Frontini, A.; Cannon, B.; Nedergaard, J.; Cinti, S. The presence of UCP1 demonstrates that metabolically active adipose tissue in the neck of adult humans truly represents brown adipose tissue. FASEB $J$. 2009, 23, 3113-3120. [CrossRef]

189. Kim, S.-N.; Jung, Y.-S.; Kwon, H.-J.; Seong, J.K.; Granneman, J.G.; Lee, Y.-H. Sex differences in sympathetic innervation and browning of white adipose tissue of mice. Biol. Sex Differ. 2016, 7, 67. [CrossRef] [PubMed] 